\title{
Appraisal of the Water Resources of the Big Sioux Aquifer, Moody County, South Dakota
}

\author{
U.S. GEOLOGICAL SURVEY
}

Water-Resources Investigations Report 87-4057

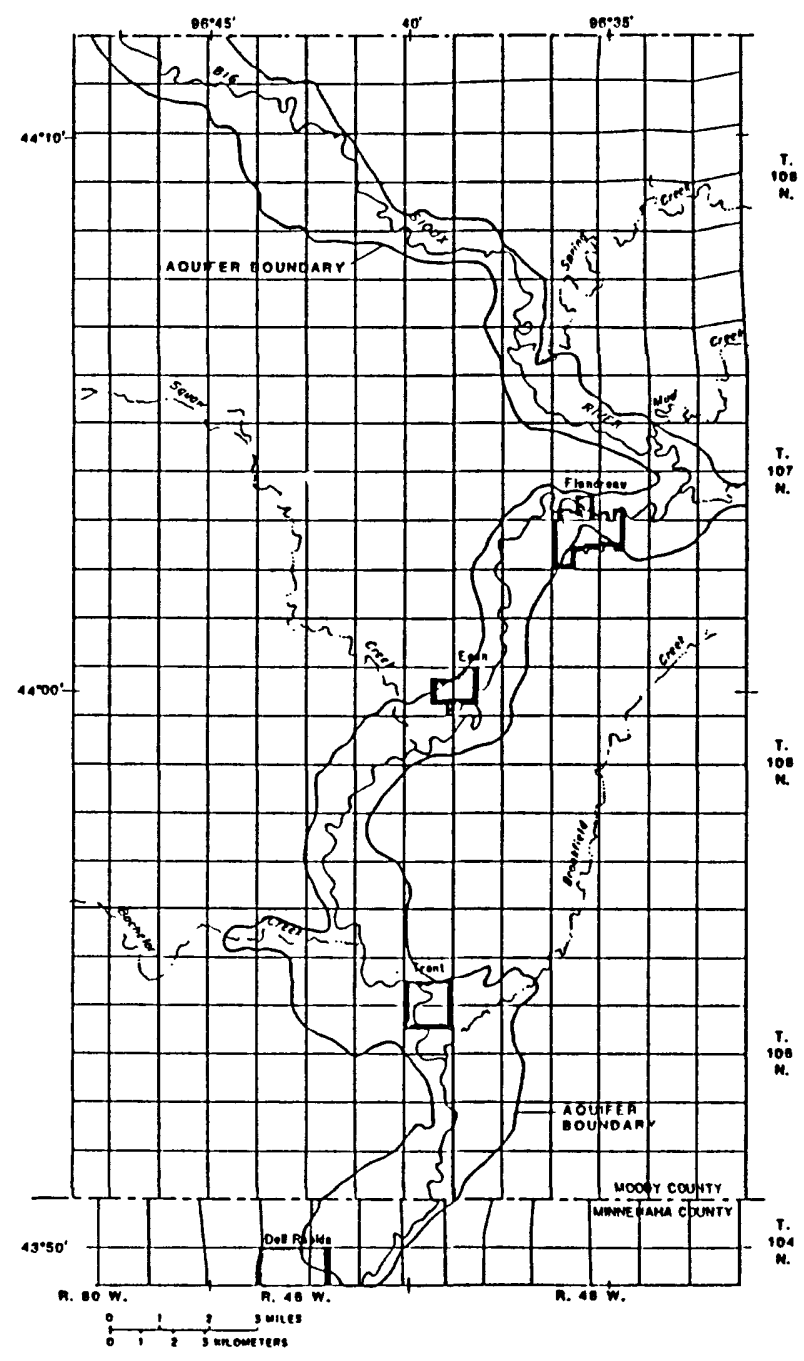

Prepared in cooperation with the SOUTH DAKOTA DEPARTMENT OF WATER AND NATURAL RESOURCES, EAST DAKOTA WATER DEVELOPMENT DISTRICT, and MOODY COUNTY

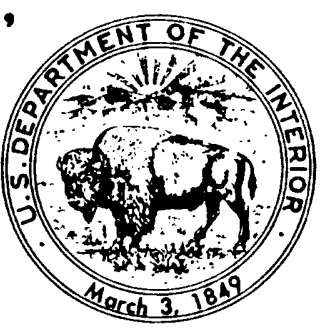


APPRAISAL OF THE WATER RESOURCES

OF THE BIG SIOUX AQUIFER,

MOODY COUNTY, SOUTH DAKOTA

By Donald S. Hansen

U.S. GEOLOGICAL SURVEY

Water-R esources Investigations Report $87-4057$

Prepared in cooperation with the

SOUTH DAKOTA DEPARTMENT OF

WATER AND NATURAL RESOURCES,

EAST DAKOTA WATER DEVELOPMENT DISTRICT, and MOODY COUNTY

Huron, South Dakota

1988 
UNITED STATES DEPARTMENT OF THE INTERIOR

DONALD PAUL HODEL, Secretary

GE OLOGICAL SURVEY

Dallas L. Peck, Director

For additional information write to:

District Chief

U.S. Geological Survey

Rm. 317, Federal Bldg.

2004 th St. SW

Huron, SD 57350
Copies of this report can be purchased from:

U.S. Geological Survey Books and Open-File Reports Federal Center, Bldg. 810 Box 25425

Denver, CO 80225-0425 
Abstract . . . . . . . . . . . . . . . . . . . . 1

Introduction ............................... 2

Purpose and approach to the study . . . . . . . . . . . . . 2

Well-numbering system ...................... 2

Acknowledgments ...................... 5

Aquifer description . . . . . . . . . . . . . . . . . . . . 5

Description of the project area . . . . . . . . . . . . . 5

Aquifer characteristics .. . . . . . . . . . . . . . 5

Recharge and discharge .. . . . . . . . . . . . . . . 8

Assumptions, description, and structure represented in the model . . . . . 12

Aquifer characteristics represented in the model . . . . . . . . . 13

Aquifer recharge and discharge represented in the model . . . . . . . 13

Model description . . . . . . . . . . . . . . . . . 15

Model calibration and application . . . . . . . . . . . . . 17

Steady-state condition . . . . . . . . . . . . . . . . . 17

Transient condition . . . . . . . . . . . . . . . . . . 20

Sensitivity analysis for steady-state conditions . . . . . . . . . 25

Analysis of hypothetical hydrologic situations . . . . . . . . . . . 25

Severe 1976 drought conditions, hypothetical situation 1 . . . . . . 28

Increased withdrawals, steady-state conditions,

hypothetical situation 2 . . . . . . . . . . . . 29

Increased withdrawals during severe drought conditions,

Model limitations .......................... 36

Summary . . . . . . . . . . . . . . . . . . . . . . 36

Selected references . . . . . . . . . . . . . . . . . 37 


\section{ILLUSTRATIONS}

Figure 1. Map showing location of the Big Sioux basin, previous study

Page areas, and the area for this report ........... 3

2. Well-numbering diagram .............. 4

3. Map showing thickness of sand and gravel in the Big Sioux aquifer ............... 6

4. Geologic section $A-A^{\prime}$ showing the Big Sioux and Howard aquifers . . 7

5. Water-level fluctuations in the Big Sioux aquifer and cumulative departure from normal precipitation at Flandreau, S. Dak. . . . . 9

6. Map showing average water table of the Big Sioux aquifer, base period 1970-79................. 11

7. Map showing boundary conditions represented in the model and location of observation and pumping wells used for steady-state simulation . . . . . . . . . . . . 14

8. Map showing al titude of base of the Big Sioux aquifer . . . . . 16

9. Map showing contours of steady-state water surface simulated by the model . . . . . . . . . . . . . 18

10. Hydrographs showing comparison of simulated and measured water levels and percent accuracy of six wells completed in the Big Sioux aquifer, $1983 \ldots \ldots 23$

11. Map showing comparison of computer-simulated and measured potentiometric surfaces in the Big Sioux aquifer . . . . . . 24

12. Map showing simulated drawdown after 12 months of pumping under drought conditions (1976), hypothetical situation 1 . . . 30

13. Map showing simulated steady-state drawdown under increased withdrawals, hypothetical situation 2 . . . . . . 33

14. Map showing simulated drawdown after 12 months of pumping under drought (1976) conditions with increased withdrawals, hypothetical situation $3 \ldots . . . . . . .35$

\section{TABLES}

Table 1. Most likely value and plausible range of aquifer characteristics ... 8

2. Simulated hydrologic budget for the steady-state model . . . . . 19

3. Comparison of measured and simulated water-level decline in 27 observation wells, April to October $1983 \ldots . . . . .21$

4. Summary of differences between measured and simulated water levels during 1983 by month . . . . . . . . . . 22

5. Simulated monthly changes in the water supply of the

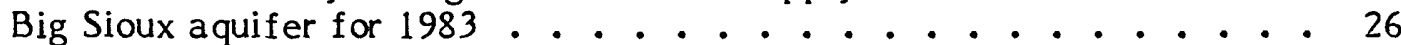

6. Summary of sensitivity analysis for steady-state conditions . . . . . 27

7. Monthly hydrologic conditions and pumping rates for severe drought conditions (1976), hypothetical situation $1 \ldots \ldots 28$

8. Simulated monthly changes in the water supply for the Big Sioux aquifer under drought conditions (1976), hypothetical situation 1 . . 31

9. Increased withdrawals, steady-state conditions, hypothetical situation 2....................... 32

10. Simulated monthly changes in the water supply for the Big Sioux aquifer under severe (1976) drought conditions under increased withdrawals, hypothetical si tuation $3 \ldots 34$ 


\section{CONVE RSION FACT ORS}

For those readers who may prefer to use SI units rather than inch-pound units, the conversion factors for the terms in this report are listed below:

Mul tiply inch-pound unit

acre-foot (acre-ft)

acre-foot per year (acre-ft/yr)

foot (ft)

foot per day (ft/d)

foot per mile ( $\mathrm{ft} / \mathrm{mi}$ )

cubic foot per second $\left(\mathrm{ft}^{3} / \mathrm{s}\right)$

gallon per minute (gal/min)

inch

inch per year (in/yr)

mile (mi)

square mile $\left(\mathrm{mi}^{2}\right)$
By

0.001234

1,233

0.3048

0.3048

0.1894

0.028317

0.06308

25.40

25.40

1.609

2.590
To obtain SI unit

cubic hec tometer cubic meter per year meter

meter per day meter per kilometer cubic meter per second liter per second millimeter millimeter per year kilometer square kilorneter 


\title{
APPRAISAL OF THE WATER RESOURCES OF THE \\ BIG SIOUX AQUIFER, MOODY COUNTY, SOUTH DAKOTA
}

\author{
By Donald S. Hansen
}

\begin{abstract}
ABST RACT
The Big Sioux aquifer in Moody County is a 55-square-mile, water-table aquifer hydraulically connected to the Big Sioux River. The average thickness is $22 \mathrm{feet}$ and the maximum thickness is 54 feet. The aquifer is underlain by relatively impermeable glacial till and is bounded to the south, near Dell Rapids, by relatively impermeable quartzite.

A digital model was developed to simulate ground-water flow in the Big Sioux aquifer in Moody County. The model was calibrated for steady-state conditions using average annual water levels, average recharge, evapotranspiration, well pumpage, river stage, and base-flow discharge in the Big Sioux River from 1970 through 1979. Steadystate simulated water levels from 11 wells averaged 0.4 feet higher than measured water levels. The average absolute difference between measured and simulated water levels was $1.57 \mathrm{feet}$.

The model was calibrated for transient conditions using 1983 water levels. Measured water levels were compared to simulated water levels in 27 observation wells. The average monthly difference between measured and simulated water levels was $2.63 \mathrm{feet}$. The absolute value of the average monthly difference between measured and simulated water levels was $3.32 \mathrm{feet}$. The average measured water-level decline from April to October 1983 was $4.57 \mathrm{feet}$ compared to a simulated water-level decline from April to October of 3.18 feet.
\end{abstract}

Sensitivity analyses showed that recharge rate and evapotranspiration extinction depth had the largest effect on simulated water levels. A 4-inch per year increase in the recharge rate caused simulated water levels to rise $1.7 \mathrm{feet}$. A 2.5 -foot increase in the evapotranspiration extinction depth caused simulated water levels to decline an average of $0.8 \mathrm{feet}$.

The calibrated model was used to simulate the effects of three hypothetical hydrologic situations. The first situation simulated the transient effects of 1983 pumpage under severe drought conditions. Water in storage was not depleted in any of the model's nodes during one year's simulation. The second hypothetical situation simulated the steady-state effects of pumping at a rate of 5,200 acre-feet per year from 50 hypothetical wells evenly spaced throughout the aquifer under average hydrologic conditions determined for the period 1970-79. The third hypothetical situation simulated the transient effects of pumping an additional 5,200 acre-feet per year from 50 hypothetical wells under severe drought conditions. Stored water was not depleted in any nodes after 12 months of pumping. 


\section{INTRODUCTION}

The Big Sioux River basin has a drainage area of about $9,000 \mathrm{mi}^{2}$ in eastern South Dakota, southwestern Minnesota, and northwestern Iowa (fig. 1). The basin is about $210 \mathrm{mi}$ long and $65 \mathrm{mi}$ wide, and extends from northern Day to southern Union County. The Big Sioux aquifer is a glacial-drift aquifer, covering nearly the entire length of the Big Sioux River.

The water resources of the Big Sioux River basin are being used at an everincreasing rate. Irrigation and rural-water systems have been developed in the basin. The Big Sioux River is hydraulically connected with the Big Sioux aquifer, and lack of knowledge about the interaction between ground water and surface water could lead to overdevelopment of the water resources in some areas. This potential overdevelopment could effect downstream users.

This study is part of a comprehensive study that includes the entire Big Sioux River basin in South Dakota. For the past 20 years, water studies have included parts of the Big Sioux basin. These studies have been completed as county, unit, or city studies and were designed for a specific purpose. They were never intended to evaluate the water resources of the entire basin. As a result, water development has been rapid in some areas while in other areas of the basin, rapid water development has not been permitted. The result is a haphazard development pattern that does not efficiently utilize the available water resources. The Big Sioux basin hydrologic study is a comprehensive investigation of the entire basin and includes the water-resource investigation of 5 counties that have not previously been studied under the State cooperative county study program.

\section{Purpose and Approach to the Study}

The general purpose of the Big Sioux basin hydrologic study is to provide the hydrologic information and analytical capability needed for effective management of the ground-water resources of the Big Sioux basin. The specific purposes of this study are to: (1) Describe the Big Sioux aquifer system in Moody County; (2) construct and calibrate a digital computer model of the Big Sioux aquifer system along the Big Sioux River, to be used as a management tool in assessing future hydrologic conditions; and (3) evaluate the effects of man-induced and natural stresses on ground-water levels in the a quifer and streamflow in the Big Sioux River.

The study approach was to gather sufficient hydrologic data from the Big Sioux aquifer in Moody County to be used as input data for the digital model. The model uses a set of mathematical equations describing ground-water flow that are solved using a computer program. The model numerically simulates the flow of water through the aquifer. The use of the model improves the understanding of the aquifer system. Once the model is adjusted to represent transient conditions, it may be used to determine the probable response of the aquifer system in Moody County to man-induced stresses, such as pumping, and natural stresses, and drought. New plans for irrigation or other forms of water use can be tested by changing the rates and distribution of withdrawal in the model. Such model simulations can be produced rapidly.

\section{Well-Numbering System}

The wells and test holes are numbered according to a system based on the Federal land survey of eastern South Dakota (fig. 2). 


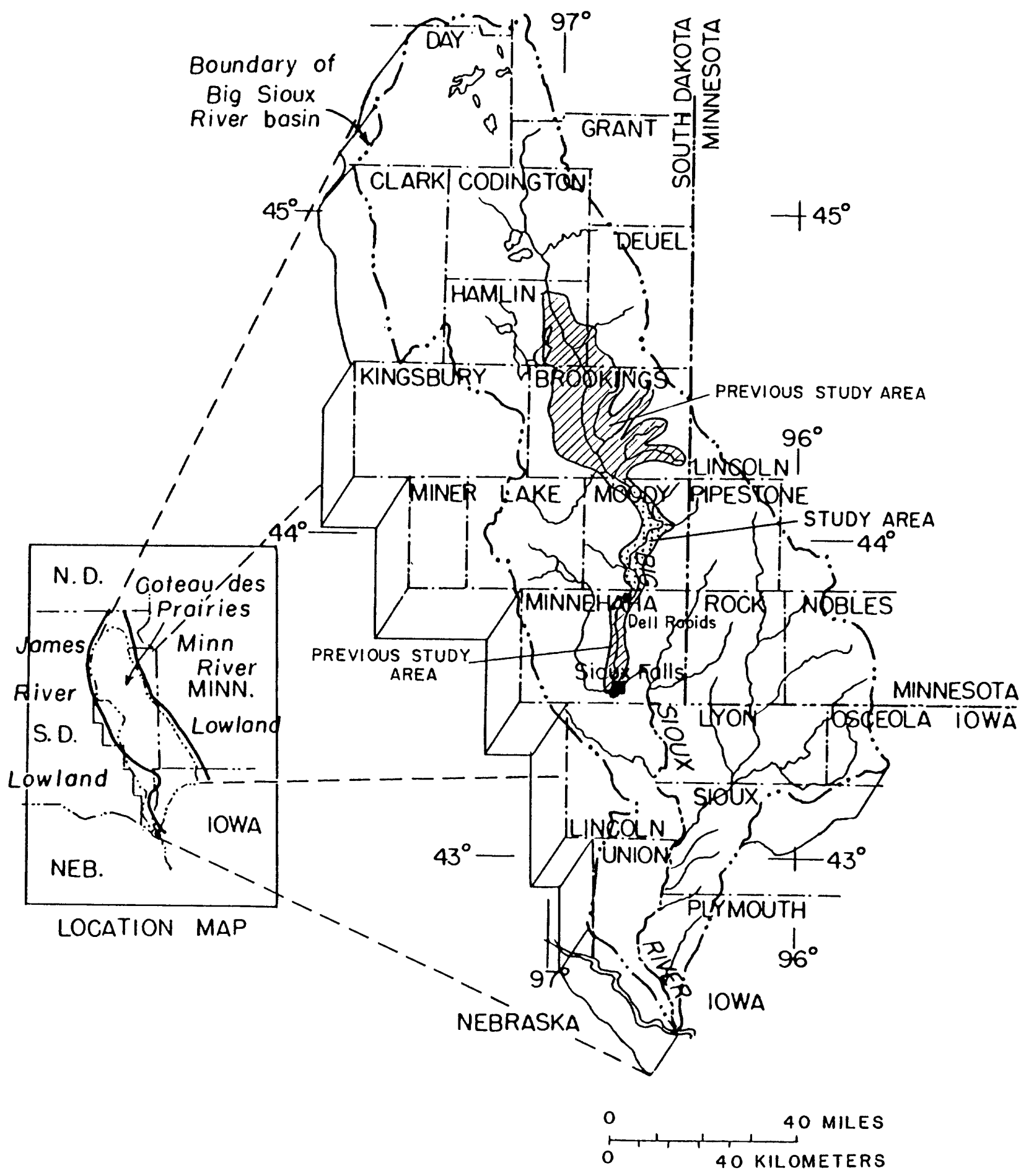

Figure 1.--Location of the Big Sioux River basin, previous study areas, and the area for this report. 


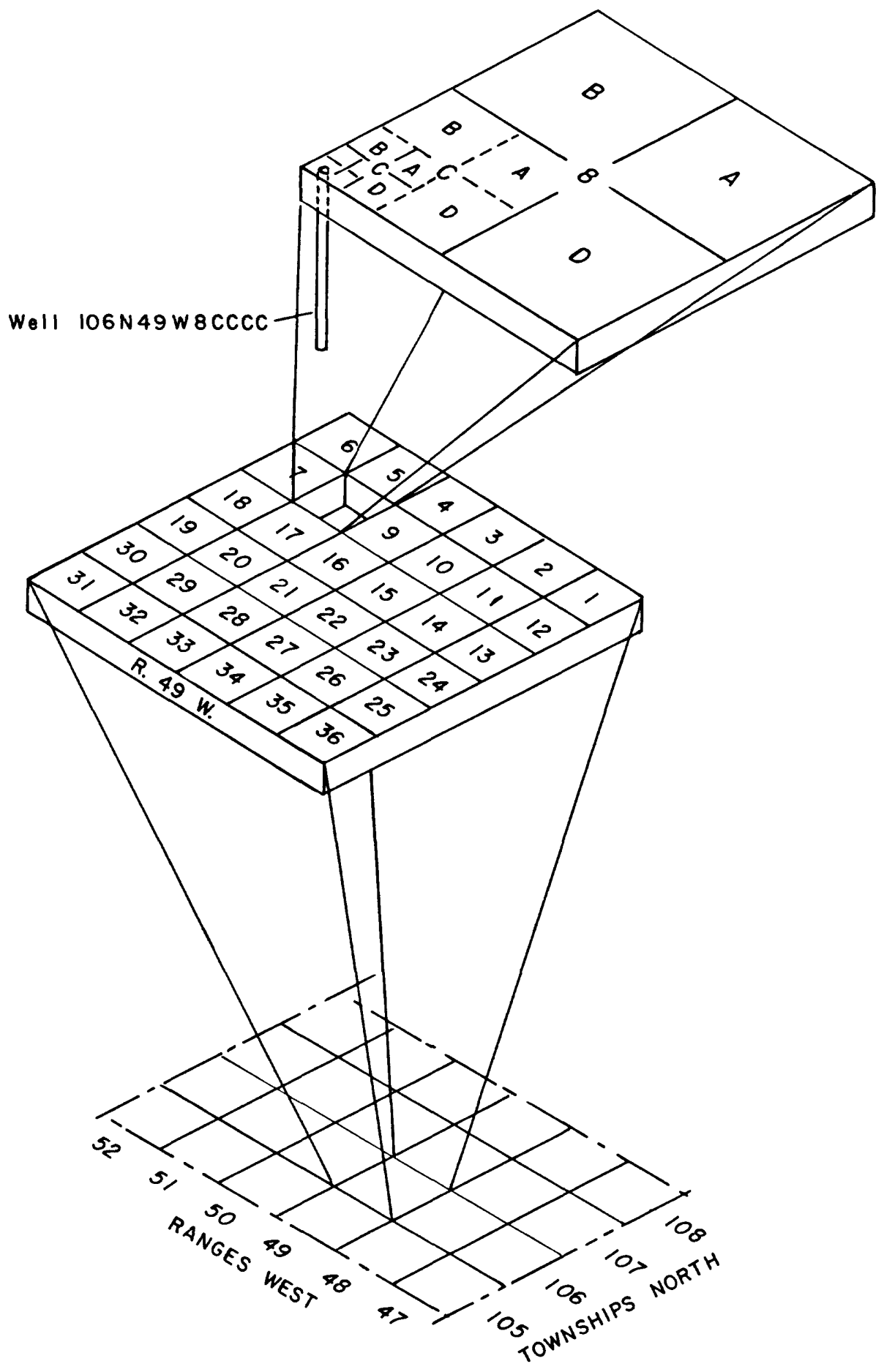

Figure 2.--Well-numbering diagram. The well number consists of township followed by "N," range followed by "W," and section number, followed by a maximum of four uppercase letters that indicate, respectively, the $160_{-}, 40-, 10_{-}$, and $2 \frac{1}{2}-$ acre tract in which the well is located. These letters are assigned in a counter clockwise direction beginning with "A" in the northeast quarter. A serial number following the last letter is used to distinguish between wells in the same tract. 


\section{Acknowledgments}

Appreciation is expressed to the well drillers, county and municipal officials, and irrigators in the study area for their cooperation, help, and inf ormation provided.

\section{AQUIFE R DESCRIPTION}

\section{Description of the Project Area}

The project area is within the Coteau des Prairies, a highland plateau occurring between the Minnesota River lowland to the east and the James River lowland. to the west (fig. 1). A topographic linearity nearly parallel to the scarp-like margins of the highland was formed by moraines developed along the lateral margins of two lobes of glacial ice, one west and one east of the coteau, held apart by the wedge-shaped bedrock highland between them.

The Big Sioux River is the only large stream that drains the Coteau des Prairies. The river's course, which approximates the central axis of the coteau, seems to have been developed during one of the glacial ages when meltwater flowed southward, confined between the two glacier lobes that flanked the coteau. Most of the tributaries to the Big Sioux River flow from the east. Lakes, ponds, and marshes are more abundant west of the Big Sioux River than east of it.

The Coteau des Prairies is composed of bedrock formations overlain by unconsolidated glacial drift. Glacial drift is a term used to designate all deposits associated with glaciers. Glacial drift includes outwash and till deposits. The shallowest bedrock in the study area is the Cretaceous Pierre Shale or Precambrian Sioux Quartzite wash (Hansen, 1984), which is overlain by as much as $330 \mathrm{ft}$ of unconsolidated glacial drift. The Sioux Quartzite wash is a coarse, quartzose sand that overlies the Sioux Quartzite at most locations. The Sioux Quartzite is dense ( 2.67 grams per cubic centimeter) (Hansen, 1982) relatively impermeable orthoquartzite that outcrops in the Dell Rapids area.

\section{Aquifer Characteristics}

The ability of an aquifer to transmit water can be described by its hydraulic conductivity or by its transmissivity. Hydraulic conductivity is the volume of water that will flow in unit time through a unit area of the aquifer under a unit hydraulic gradient. Transmissivity is the product of the hydraulic conductivity and the saturated thickness. The saturated thickness of a water-table aquifer is a critical factor because it decreases in response to pumping, thus decreasing the yield or the amount of water that may be withdrawn from the aquifer.

Test-hole data showed that the Big Sioux aquifer (fig. 3) in Moody County is a $55-\mathrm{mi}^{2}$ area and consists of glacial outwash, deposited by meltwater streams. The aquifer ranges from a fine-to-medium, poorly sorted sand to a well-sorted sand and medium gravel. Gravel as much as one inch in diameter was found in T. $108 \mathrm{~N}$., R. 49 W., sec. 5, 9, and 10 . The thickness of the aquifer ranges from 4 to $54 \mathrm{ft}$ and is underlain by and is bound on the east and west by relatively impermeable till (fig. 4). This till has a hydraulic conductivity of about $5 \times 10^{-4} \mathrm{ft} / \mathrm{d}$ (Henry, 1982). The aquifer is bounded at the south, near Dell Rapids, by the Sioux Quartzite and extends to the north into Brookings County. The Big Sioux River trends north-south and is bounded by the Big Sioux aquifer. The Howard aquifer underlies the till but is not hydraulically connected to the Big Sioux aquifer. 


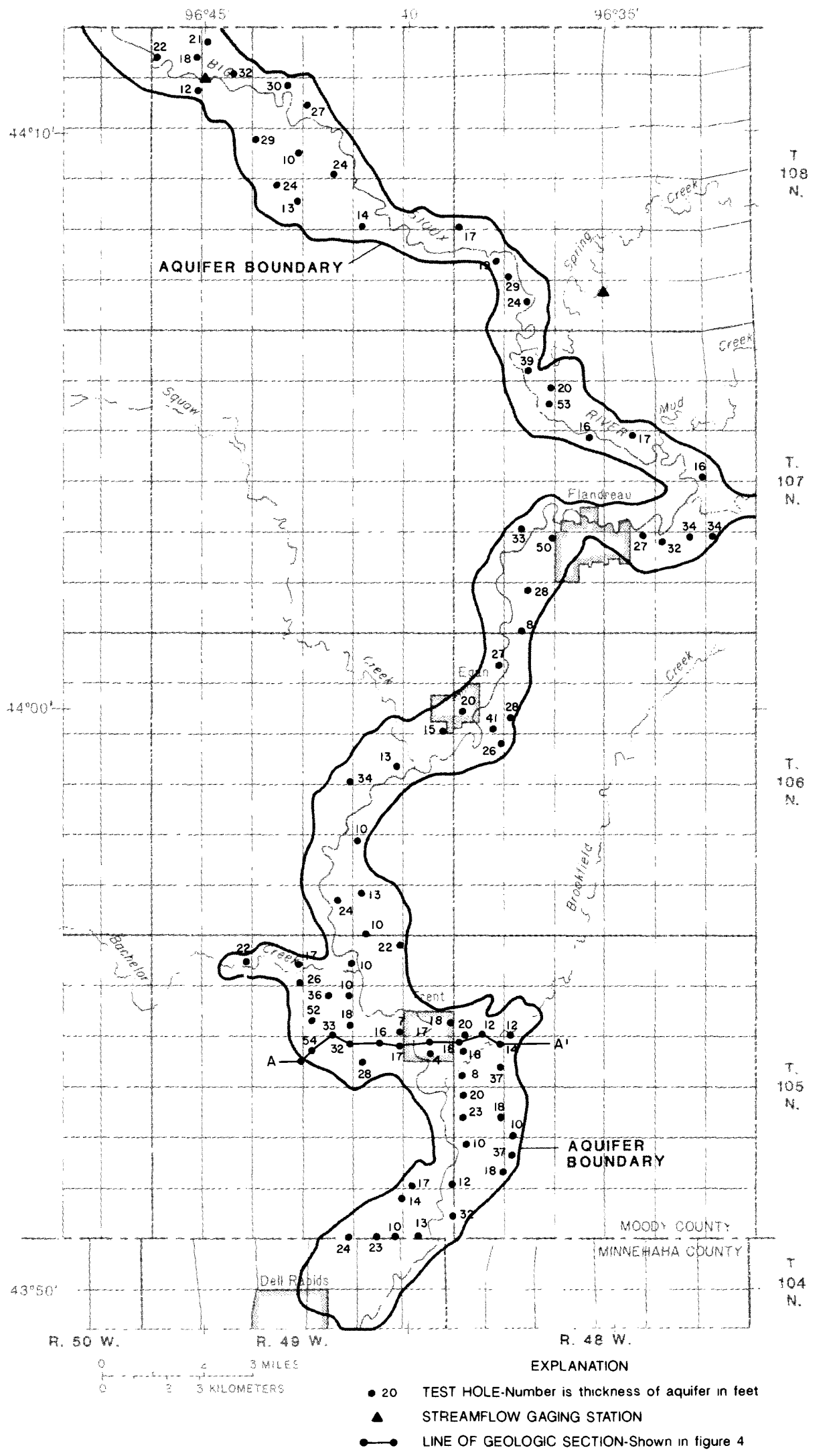

Figure 3.--Thickness of sand and gravel in the Big Sioux aquifer. 


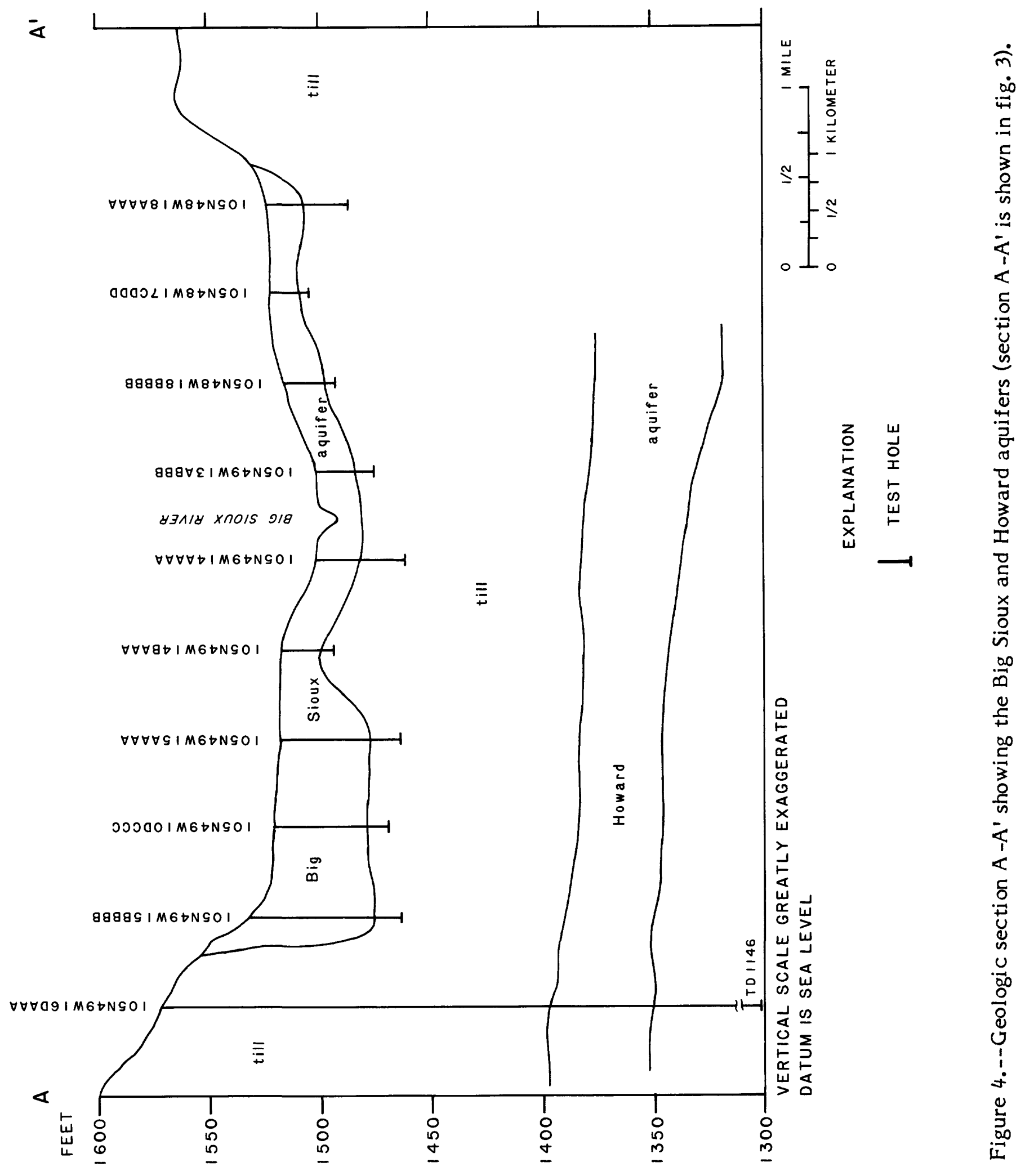


Twenty aquifer tests have been conducted (Ellis and Adolphson, 1969; Koch, 1980) in the Big Sioux aquifer in Moody, Brookings, and Minnehaha Counties. The hydraulic conductivity and associated grain size from these aquifer tests were tabulated and are shown in table 1 (Koch, 1980). The hydraulic conductivity of the aquifer outside the aquifer test area was determined by examination of samples collected during test drilling. These samples were assigned a hydraulic conductivity based on table 1 . The model was constructed using the values estimated here as most likely average value. The uncertainty in these estimates is indicated by a range of values called the plausible range.

Table 1.--Most likely value and plausible range of aquifer characteristics

[from Koch, 1980]

\begin{tabular}{lccc}
\hline \multicolumn{1}{c}{$\begin{array}{c}\text { Aquifer } \\
\text { charactistic }\end{array}$} & \multicolumn{2}{c}{ Hydraulic conductivity (feet per day) } \\
\cline { 2 - 4 } & $\begin{array}{c}\text { Lower limit } \\
\text { of plausible } \\
\text { range }\end{array}$ & $\begin{array}{c}\text { Most likely } \\
\text { average } \\
\text { value }\end{array}$ & $\begin{array}{c}\text { Upper limit } \\
\text { of plausible } \\
\text { range }\end{array}$ \\
\hline Grain size & & & \\
Clay or silt & 10 & 10 & 820 \\
Sand, very fine & 70 & 40 & 140 \\
Sand, fine & 70 & 70 & 400 \\
Sand, fine to medium & 130 & 200 & 400 \\
Sand, medium & 70 & 300 & 600 \\
Sand, fine to coarse & 130 & 400 & 800 \\
Sand, medium to coarse & 400 & 540 & 1,000 \\
Sand, coarse & 400 & 600 & 1,200 \\
Sand and gravel & 400 & 670 & 1,400 \\
Sand, coarse, and gravel & 800 & 800 & 2,000 \\
Gravel & & & \\
\hline
\end{tabular}

For unconfined conditions, the change in the volume of water in storage per unit area as the result of a unit change in hydraulic head is produced primarily by the draining or filling of pore space. This change is dependent upon pore size, rate of change of water surface, and time. Only an approximate measure of the relationship between hydraulic head and storage is obtainable for unconfined conditions. This measure is the specific yield. Aquifer tests on the Big Sioux aquifer need to be conducted for a long enough period of time to obtain an accurate specific yield. Koch (1980) reports specific yields, determined from aquifer tests, that range from 0.10 to 0.17 . Lohman (1967) has compiled specific yields for medium-to-coarse sand that range from 0.10 to 0.30 . The Big Sioux aquifer is expected to have an average specific yield of about 0.20 .

\section{$\underline{\text { Recharge and Discharge }}$}

Recharge to the aquifer is primarily by infiltration of rain and snowmelt through the overlying 1 to $2 \mathrm{ft}$ of topsoil. Ground-water levels fluctuate seasonally in response to recharge and discharge (fig. 5). Water levels rise during the spring and early summer when recharge from snowmelt and spring rains is greater than discharge by irrigation, domestic wells, and evapotranspiration. Water levels decline from mid-summer to fall or 
S $\exists$ HONI NI $\cap \cap \forall \exists \forall Q N \forall\urcorner \exists$

$\perp \forall$ NOI $\perp \forall \perp I d I 0 \exists y d 7 \forall \cap N N \forall$
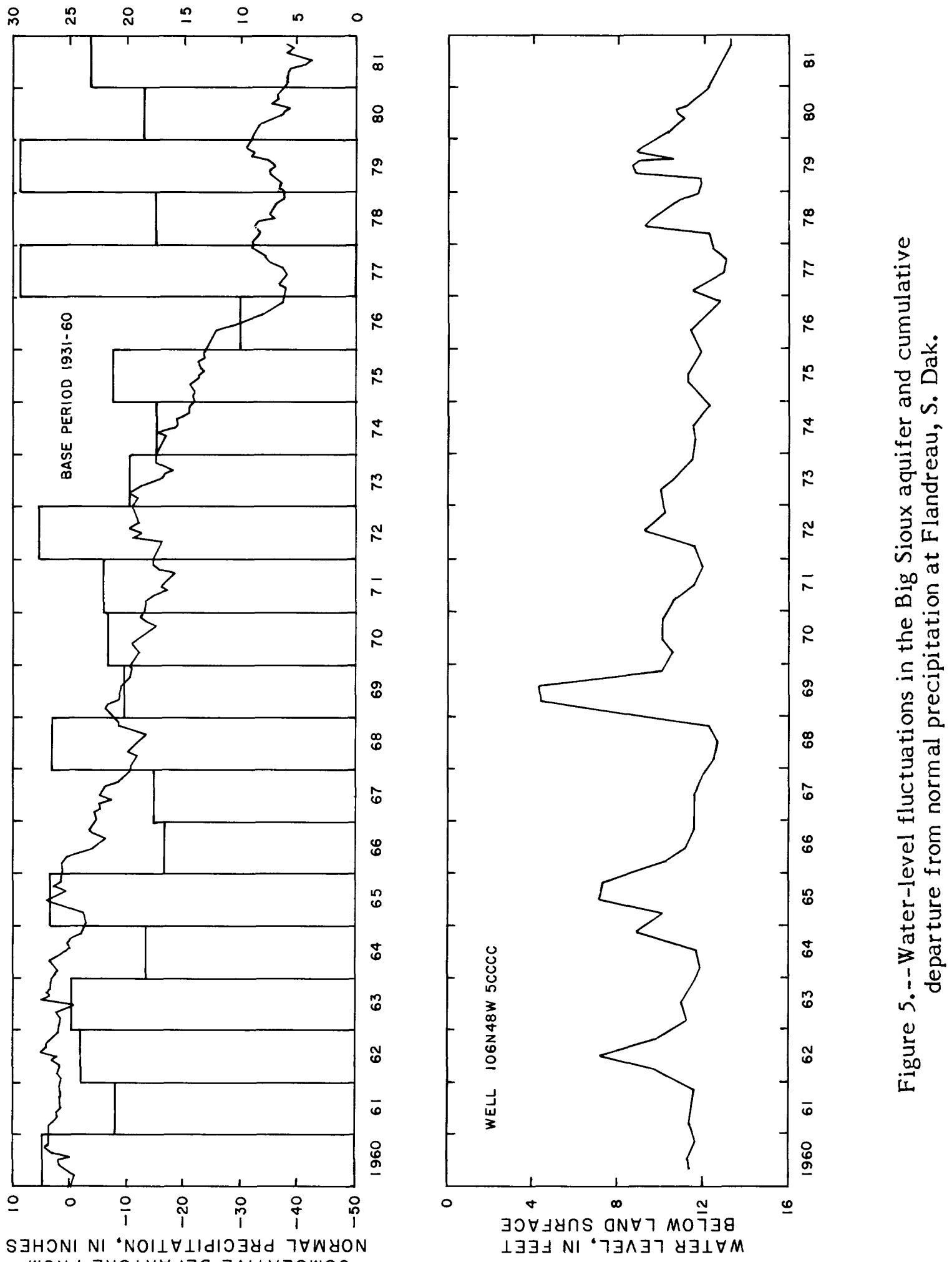
mid-winter when discharge is greater than recharge. The water level in well 106 N48W5CCCC (fig. 5) fluctuated a maximum of about $8 \mathrm{ft}$ and an average (1960-81) of about $1.55 \mathrm{ft}$. Records of long-term water-level fluctuations in well 106 N48W5CCCC show close correlation with long-term trends in precipitation. The water-level rise during 1962, 1965, 1968-69,1972, and 1978-79 was caused by above-normal precipitation. The decline from 1963-64, 1966-68,1970-71,1973-77, and 1980-81 was caused by below-normal precipitation. The range of average annual water-level rise in the 11 observation wells (fig. 6), based on the period $1970-79$, was 1.5 to $3.9 \mathrm{ft}$. The average annual water-level rise was $2.7 \mathrm{ft}$. The volume of areal recharge represented by waterlevel rise can be estimated only if the storage coefficient of the aquifer is known. The volume of water represented by a change in water level can be determined by multiplying the specific yield of the aquifer by the water-level change. Using a specific yield of 20 percent multiplied by the range of water-level rise, the calculated annual recharge to the aquifer ranged from 3.6 to 9.36 inches. The calculated average annual recharge was 6.5 inches. Using a specific yield of 15 percent, the calculated recharge ranged from 2.7 to 7.02 inches and averaged 4.86. Koch (1980) determined from observation wells that recharge to the Big Sioux aquifer $20 \mathrm{mi}$ south and $20 \mathrm{mi}$ north of this study area was about 6 inches.

One of the two additional sources of recharge to the aquifer is from uncontrolled flowing wells in T. 105 N., R. 48 W. that are completed in the underlying Howard aquifer. About 10 flowing wells discharge an average of $5 \mathrm{gal} / \mathrm{min}$ each on the land surface and locally recharge the aquifer about $80 \mathrm{acre}-\mathrm{ft} / \mathrm{yr}$. Although another source of recharge to the aquifer could be leakage from the underlying till, the till is relatively impermeable and the total volume of leakage to the aquifer in Moody County is negligible.

The general direction of water movement in the aquifer is to the south and toward the Big Sioux River which flows from north to south (fig. 6). The gradient of the watertable surface is about $6 \mathrm{ft} / \mathrm{mi}$, however, in the Trent area, the gradient is as much as $15 \mathrm{ft} / \mathrm{mi}$. Samples obtained from test drilling indicate that the aquifer is composed of fine sand in the Trent area. The higher gradients in this area may be caused by decreased aquifer hydraulic conductivity and reduced aquifer thickness in this area.

Discharge from the Big Sioux aquifer is by evapotranspiration, flow to the Big Sioux River, and by pumping from irrigation, domestic, municipal, and stock wells. The average annual pan evaporation rate for the period $1970-79$ was $41 \mathrm{in} / \mathrm{yr}$ (National Oceanic and Atmospheric Administration, 1970-79 annual summaries). The average annual ground-water discharge from the aquifer to the Big Sioux River, 1970-79, may be estimated by subtracting the average annual streamflow in the Big Sioux River, 1970 -79, measured at the gage near Brookings ( $10 \mathrm{mi}$ northwest of the gage) from the average annual streamflow in the Big Sioux River, 1970-79, measured at the gage at Dell Rapids. The result would be the total average annual streamflow gain, 1970-79, within this reach. The average annual streamflow gain was $57 \mathrm{ft}^{3} / \mathrm{s}$. If all the average annual tributary streamflow, 1970-79, within this reach was known and was subtracted from the average annual streamflow gain for 1970-79, the result would be the average annual ground-water contribution for 1970-79 to the river within this reach. Since records of tributary streamflow within the model area did not begin until 1981, the tributary streamflow from 1970-79 had to be estimated. Larimer (1970) describes a method to estimate average streamflow in an ungaged tributary, based on drainage area, landsurface vegetation, average precipitation, and soil characteristics. The average annual tributary streamflow for 11 ungaged tributaries obtained by Larimer's method was about $24 \mathrm{ft}^{3} / \mathrm{s}$. The average annual ground-water discharge to streamflow using the above method was equal to $33.86 \mathrm{ft}^{3} / \mathrm{s}\left(57.34 \mathrm{ft}^{3} / \mathrm{s}\right.$ minus $\left.24 \mathrm{ft}^{3} / \mathrm{s}\right)$. 


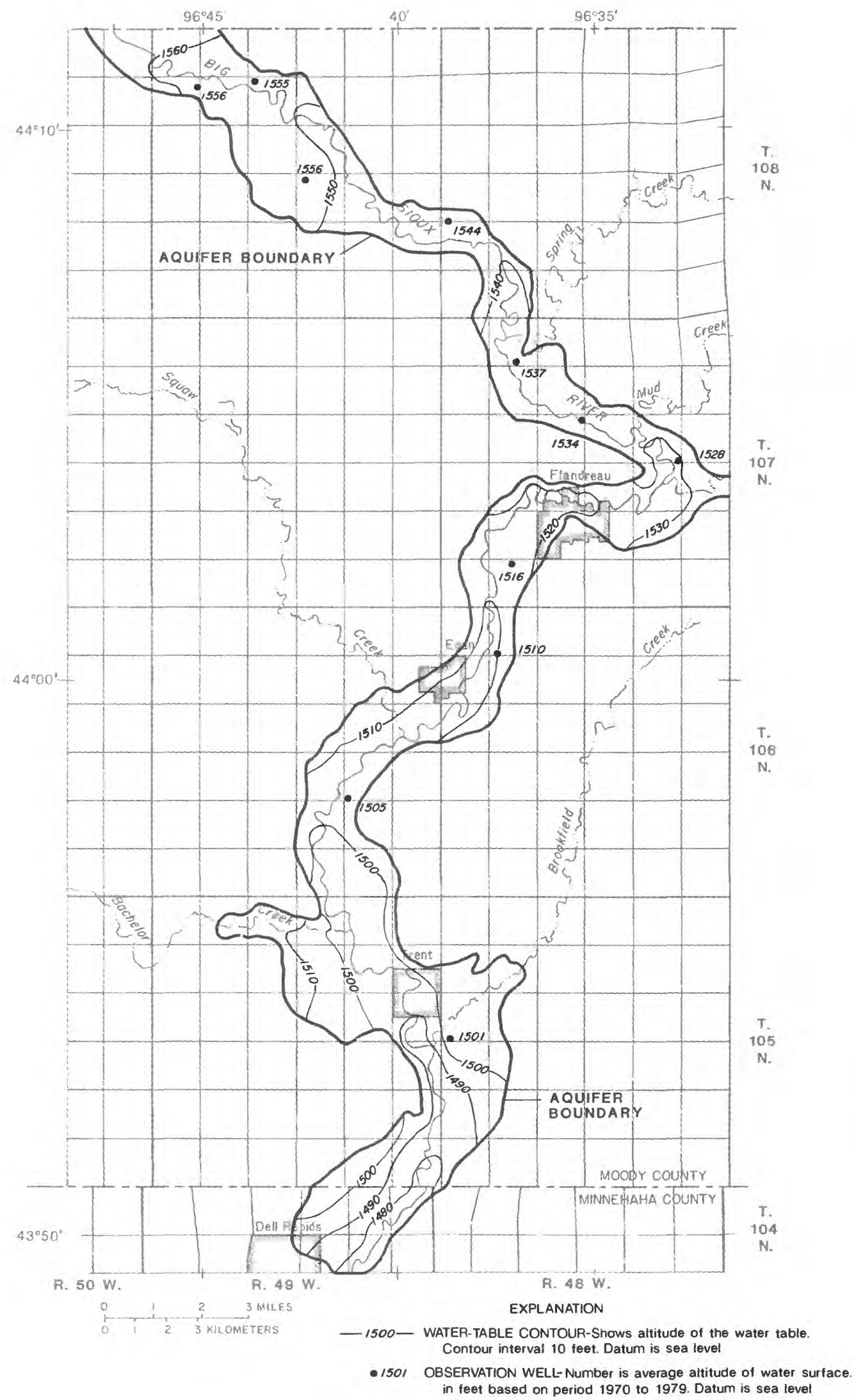

Figure 6.--Average water table of the Big Sioux aquifer, base period 1970-79. 
A second method was used to calculate the average annual ground-water discharge to the Big Sioux River and was based on the following assumptions: (1) Base flow is negligible during late winter and spring because of snowmelt and rainfall runoff; (2) flow in intermittent tributaries from July through December is negligible; and (3) overland runoff does not occur from June to December. Eleven percent of the streamflow at Dell Rapids is contributed by Flandreau and Spring Creeks, based on 1981-84 streamflow gaging station records on Flandreau and Spring Creeks. An assumption was made that an average of 11 percent $\left(10 \mathrm{ft}^{3} / \mathrm{s}\right)$ of the streamflow at Dell Rapids was contributed by Flandreau and Spring Creeks from July through December 1970-79. The $10 \mathrm{ft}^{3} / \mathrm{s}$ was subtracted from the $18.5 \mathrm{ft}^{3} / \mathrm{s}$ average Big Sioux River streamflow gain from July through December 1970-79 between the Brookings and Dell Rapids gages to arrive at the calculated ground-water discharge of $8.5 \mathrm{ft}^{3} / \mathrm{s}$. The average annual streamflow in the Big Sioux River at Dell Rapids is $260 \mathrm{ft}^{3} / \mathrm{s}$. The minimum streamflow measurement error is 5 percent $\left(13 \mathrm{ft}^{3} / \mathrm{s}\right)$, thus the estimates of base flow are at or near the measurement error.

Discharge by irrigation and municipal wells was obtained from annual irrigation reports supplied by the South Dakota Water Rights Commission and from pumpage records from municipalities. The average pumping rate for irrigation and municipal wells for the period $1970-79$ was $3.1 \mathrm{ft}^{3} / \mathrm{s}$.

\section{Assumptions, Description, and Structure Represented in the Model}

The model was developed based on the previous discussion of the geohydrologic setting, aquifer characteristics, aquifer recharge and discharge, and aquifer boundaries. A number of simplifying assumptions were used in the model to make it possible to describe the aquifer mathematically. The hydrologic assumptions used in the model of the Big Sioux aquifer are:

(1) The Big Sioux aquifer is an unconfined (water-table) aquifer;

(2) The aquifer is hydraulically connected to the Big Sioux River;

(3) The predominant direction of flow in the aquifer is horizontal;

(4) Recharge to the aquifer is from infiltration of precipitation;

(5) Ground water is discharged by evapotranspiration, leakage to the Big Sioux River, and pumpage from wells;

(6) The stream stage remains constant throughout the steady-state simulation. Under transient conditions, the stream stage is raised or lowered each month by an amount measured at the gages on the Big Sioux River near Brookings and at Dell Rapids, and at the bridges which cross the Big Sioux River;

(7) The leakage rate to or from the aquifer through the streambed is constant throughout the steady-state simulation;

(8) The evapotranspiration rate is a linear function of the depth of the water table below land surface. A way from the river, evapotranspiration rate is maximum where the water table is at land surface and decreases linearly to zero where the water table is at $5 \mathrm{ft}$ below land surface. At the river nodes, evapotranspiration decreases linearly to zero where the water table is at $10 \mathrm{ft}$;

(9) The irrigation water applied is entirely consumed by crops; and

(10) The transmissivity of the aquifer varies with the altitude of the water table. For each time step, transmissivity is calculated as the product of hydraulic conductivity and saturated thickness. 
The model grid of 103 rows and 53 columns was superimposed over the aquifer (fig. 7). Each cell covers $0.25 \mathrm{mi}^{2}$ and represents a unit volume of aquifer where groundwater flow is occurring. The center of a cell is referred to as a node. Figure 7 shows the location of the no-flow boundaries, the nodes that represent hydraulic head dependent boundaries, and nodes that represent observation wells and pumping wells.

\section{Aquifer Characteristics Represented in the Model}

Aquifer characteristics must be estimated for each cell in the model. The characteristics to be estimated are hydraulic conductivity and specific yield. The testhole data indicated that the hydraulic conductivity varies spatially within the Big Sioux aquifer. The approach used for this study was to estimate, from the test-hole data, the hydraulic conductivity using table 1. Since test-hole data was not available in every cell of the model, hydraulic conductivity was interpolated between cells of known hydraulic conductivity. If the simulation of steady-state conditions was contradicted by the available data, the hydraulic conductivity could be varied within the plausible range (table 2) to resolve the contradiction. The sensitivity of the model to hydraulic conductivity was tested and results appear in the section on "Model sensitivity." The hydraulic conductivity assigned to the model ranged from 200 to $450 \mathrm{ft} / \mathrm{d}$ depending on grain size, and specific yield was 0.2 .

\section{Aquifer Recharge and Discharge Represented in the Model}

Steady-state conditions were assumed to be the average hydrologic conditions (water levels, evapotranspiration, precipitation, and streamflow) for 1970-79. This period was chosen because both above-and below-average precipitation occurred during this time.

The approach to recharge by infiltration of precipitation adopted for this study was to estimate, from the observation well data, the most likely average value for the model area. The plausible range for recharge was based on the average water-level rise in observation wells multiplied by the plausible range of specific yield of the aquifer (table 1). If the simulation of steady-state conditions was contradicted by the observed water levels, the recharge could be varied within the plausible recharge range. The plausible recharge range, as determined by observation wells and assuming a storage coefficient of 0.2 , was 3.6 to $9.30 \mathrm{in} / \mathrm{yr}$, and the average was $6.5 \mathrm{in} / \mathrm{yr}$.

Discharge from the aquifer that may be represented in the model is leakage from the aquifer to the river, pumpage from irrigation and municipal wells, and evapotranspiration. Leakage to the river from the aquifer was simulated using head-dependent flux nodes (McDonald and Harbaugh, 1984). The river was divided into reaches, each of which is completely contained in a single cell (fig. 7). Leakage through a reach of riverbed is approximated by Darcy's law as

$$
\text { QRIV = KLW(HRIV - HAQ }) / M
$$

where

QRIV is the leakage through the reach of the riverbed $\left(\mathrm{L}^{3} \mathrm{t}^{-1}\right)$;

$\mathrm{K}$ is the hydraulic conductivity of the riverbed $\left(\mathrm{Lt}^{-1}\right)$;

$\mathrm{L}$ is the length of the reach (L);

$W$ is the width of the river (L);

$M$ is the thickness of the riverbed $(L)$;

HAQ is the head on the aquifer side of the riverbed (L); and

HRIV is the head on the river side of the riverbed $(L)$. 


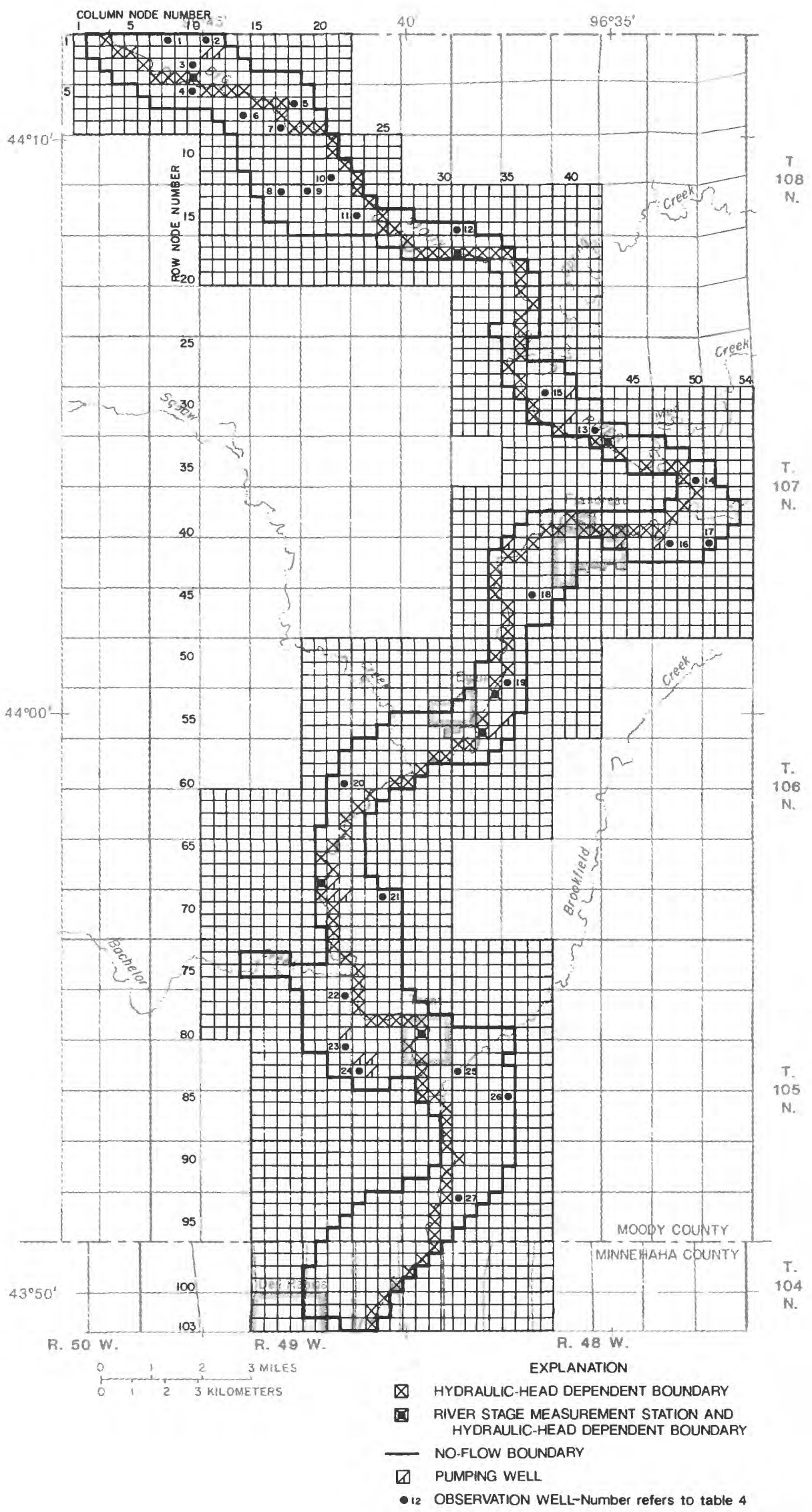

Figure 7.--Boundary conditions represented in the model and location of observation and pumping wells used for steady-state simulation. 
The average head during 1970-79 on the river side of the riverbed (HRIV) was estimated from streamflow gaging stations located at the Big Sioux River near Brookings and Dell Rapids. The number of stream reaches was divided into the stage difference between the gages and the result was subtracted from the stage of the upstream reach. The average head from 1970 to 1979 on the aquifer side of the river was estimated from water levels in 11 observation wells (fig. 6).

The hydraulic conductivity of the streambed ranged from 0.5 to $1.0 \mathrm{ft} / \mathrm{d}$ (Jorgensen and Ackroyd, 1973). The average (1970-79) width of the streambed, measured at the streamflow gaging stations, was about $80 \mathrm{ft}$. The length of the riverbed was measured in each cell from U.S. Geological Survey 7.5 minute topographic maps. Thickness of the riverbed was arbitrarily assumed to be $1 \mathrm{ft}$.

The ten-year average for irrigation and municipal pumpage for Flandreau, Trent, and the Big Sioux rural water system was 1,200 acre-ft/yr. The pan evaporation rate for 1970-79 ranged from 29 to $54 \mathrm{in} / \mathrm{yr}$ and averaged $41 \mathrm{in} / \mathrm{yr}$ (NOAA, 1970-79). The assumption was made that pan evaporation was a reasonable estimate of the maximum possible rate of evapotranspiration (Eagleman, 1967). The average annual evapotranspiration rate was considered to be about 75 percent of the observed class $A$ pan data (NOAA, 1982). The plausible range of evapotranspiration was considered to be, for this study, 75 percent of 29 to $54 \mathrm{in} / \mathrm{yr}$ or about 21 to $41 \mathrm{in} / \mathrm{yr}$. The average evapotranspiration rate was considered to be $31 \mathrm{in} / \mathrm{yr}$. The plausible range for evapotranspiration extinction depth was assumed to be 0 to $10 \mathrm{ft}$ and the most likely average value to be $5 \mathrm{ft}$. The altitude of the land surface was determined from U.S. Geological Survey 7.5 minute topographic maps and altitude of the aquifer base (fig. 8) was determined from driller's logs.

\section{MODEL DESCRIPTION}

A model is a description or analogy that can be useful in visualizing something that cannot be directly observed. A digital ground-water model is a mathematical description of a geohydrologic system. A digital model can assist in analyzing a hydrologic system and can be used to make predictions for use in management decisions; the user must realize that the model is only an approximate representation of the actual system. The validity of the predictions made by the model depend on the closeness of this approximation. The digital model in this report does not permit a statement on the confidence limits bounding the projections made by the model. This needs to be done subjectively. The model results are valid to the extent that the digital model resembles the Big Sioux aquifer in the Big Sioux basin, the aquifer characteristics have the properties assumed, and the proposed stresses are the same type and magnitude as the historical stresses.

The description of the aquifer system is simple enough to allow a mathematical simulation. The mathematical description, or digital model, is used to simulate both steady-state conditions and responses to historical and projected future withdrawals. The steady-state simulation is compared with average hydrologic conditions to improve the understanding of the geohydrologic system. The comparison of the simulated response to historical withdrawals with the actual response provides a subjective measure of the model's ability to simulate the response of the hydrologic system. 


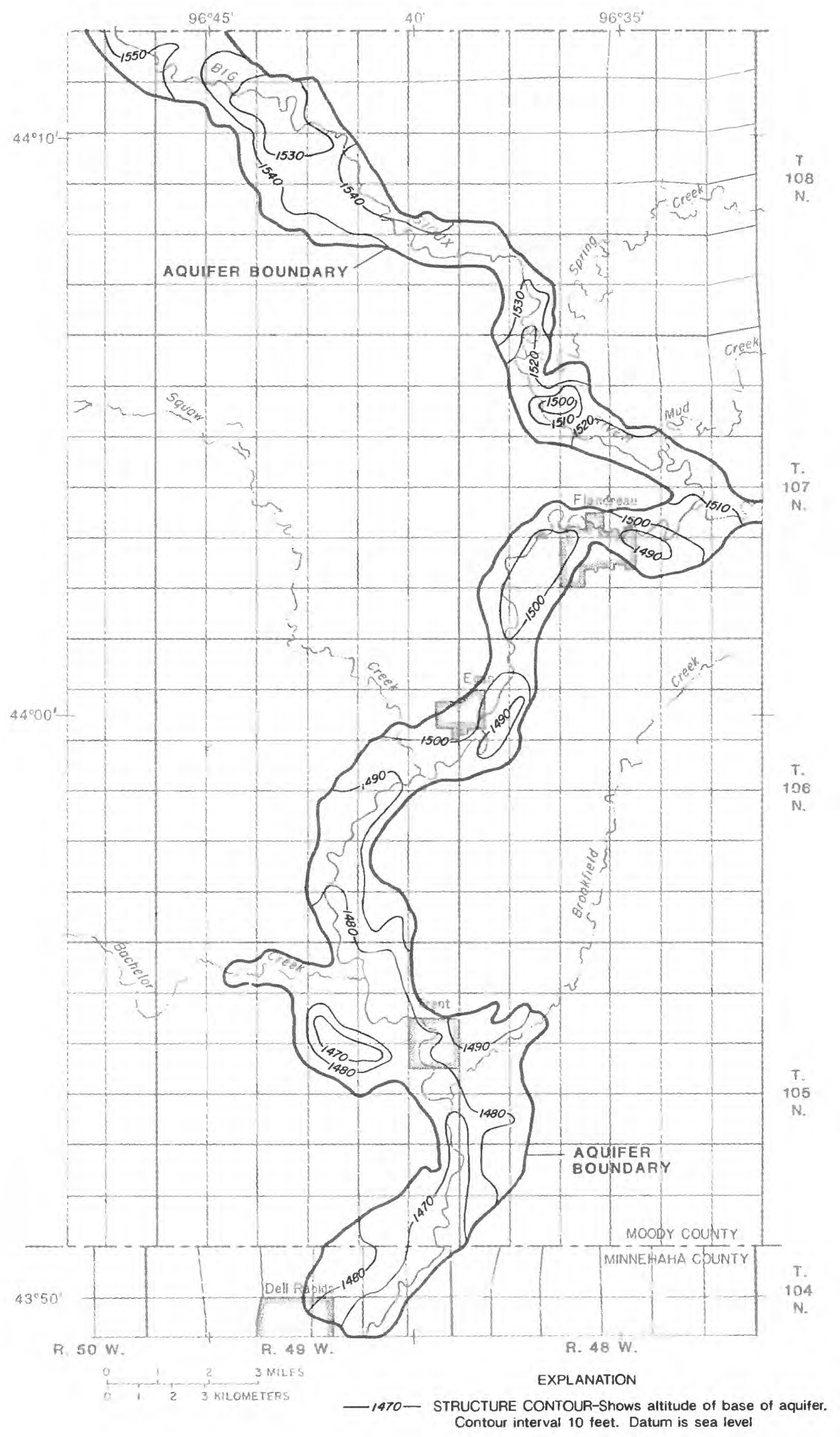

Figure 8.--Altitude of the base of the Big Sioux aquifer. 
This section of the report describes the analogy between the aquifer system and the model. The aquifer system, which includes the geohydrologic setting, aquifer characteristics, aquifer recharge and discharge, and aquifer boundaries, is discussed first. The description of the digital model follows the discussion of the aquifer system.

\section{Model Calibration and Application}

Model calibration is the process by which data are adjusted so the model will adequately simulate historical potentiometric heads. The steady-state (1970-79) hydrologic conditions were simulated by entering average recharge and evapotranspiration, and by setting the storage in the aquifer to zero. This is referred to as the steady-state or equilibrium model. The computed steady-state potentiometric heads were compared to the annual average, 1970-79, observation-well water-level data to assess the accuracy of the steady-state model. The transient model includes storage and time-dependent recharge, evapotranspiration, and pumpage. Again, the resultant transient potentiometric heads were compared to measured observation-well water-level data. Calibration involves varying the values of hydraulic conductivity, recharge, evapotranspiration, and storage to bring computed and measured potentiometric heads closer. All of the hydrologic characteristics changed were kept within the preset plausible range. The calibration was concluded when the aquifer properties simulated were within reasonable hydrologic limits, and a "best fit" between the simulated and historical water-level data was obtained.

There is some inherent error in the measured water levels and in the model results. The complexity of the aquifer can result in nonrepresentative water levels. In addition, nearby pumping can result in measured water levels which are too low. Inaccurate measurement or recording of water levels can result in additional errors. Errors in the model formulation, estimation of the hydrologic parameters, and the lateral differences between well location and node center in the model will also produce differences between the simulated water levels and the measured water levels.

\section{Steady-State Condition}

The model calibration was continued until simulated water levels in the aquifer acceptably matched corresponding measured water levels (fig. 9) and when simulated leakage from the aquifer to the river approximated the estimated base flow of the river $\left(8.5 \mathrm{ft}^{3} / \mathrm{s}\right)$. Steady-state conditions were simulated with the hydraulic conductivity distributed areally, based on test-hole data. Steady-state conditions were also simulated with a uniform, $400-\mathrm{ft} / \mathrm{d}$ hydraulic conductivity throughout the aquifer. The uniform hydraulic conductivity improved the match between simulated and measured water levels. The hydraulic conductivity in rows 50 to 103 of the aquifer was reduced from 400 to $300 \mathrm{ft} / \mathrm{d}$ because of the fine to coarse sand found during test drilling. This reduced hydraulic conductivity additionally improved the match between measured and simulated heads. Recharge was adjusted uniformly over the entire model area. The model was sensitive to recharge. Adjustments to recharge, to obtain a close match between the simulated and measured water levels were limited to the plausible range of 3.6 to $9.3 \mathrm{in} / \mathrm{yr}$. The closest match between water levels occurred when recharge was $5.9 \mathrm{in} / \mathrm{yr}$. Adjustment in the evapotranspiration rate from $31 \mathrm{in} / \mathrm{yr}$ failed to significantly improve the match. Adjustments in evapotranspiration extinction depth did, however, improve the match for observation wells near the Big Sioux River. Simulated water levels in wells adjacent to the river were about 1.5 to $3.0 \mathrm{ft}$ higher than measured water levels. When an evapotranspiration extinction depth was increased from 5 to $7 \mathrm{ft}$ in the nodes containing the hydraulic head dependent boundary (river reach nodes, fig. 7), the 


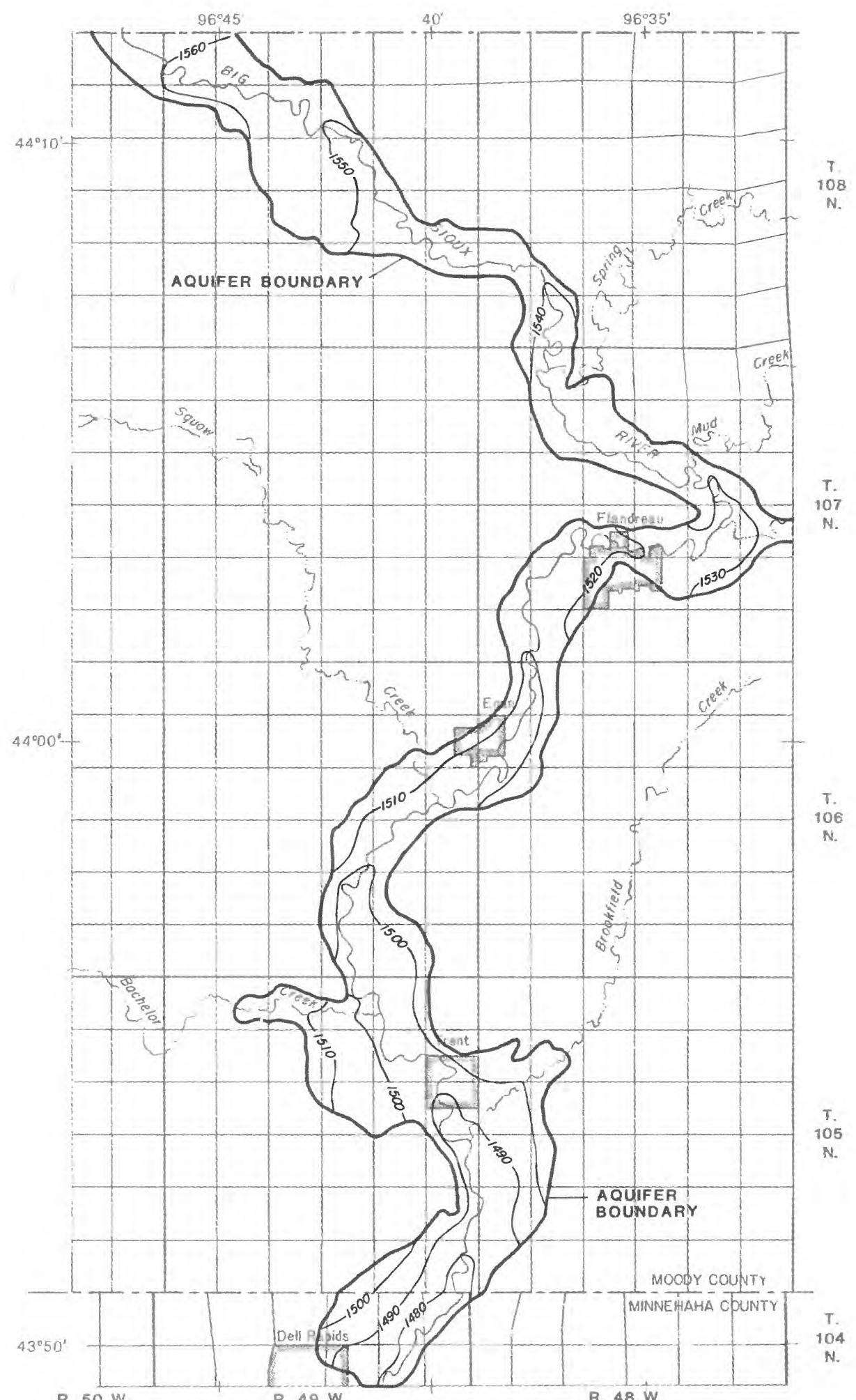

R. $50 \mathrm{~W}$.

R. $49 \mathrm{~W}$.

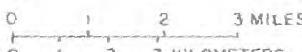

A. $48 \mathrm{~W}$.

Figure 9.--Contours of steady-state water surface simulated by the model. 
simulated water levels were decreased to a level 0.5 to $1.5 \mathrm{ft}$ higher than measured water levels. Higher simulated water levels may have been caused by not accounting for transpiration from cottonwood trees, which have roots extending greater than $5 \mathrm{ft}$, along the river, or the streambed leakance was set too small and maintained elevated heads along the river. A larger river leakance was set and improved the match near the river, but the match of wells located away from the river worsened. A smaller node spacing along the river may improve the match between simulated and measured water levels, however, it is not possible to implement a smaller node spacing along a meandering stream using the MCDonald-Harbaugh model. Adjustments to hydraulic conductivity of the streambed, within the plausible range of 1.0 to $10 \mathrm{ft} / \mathrm{d}$, changed the simulated base flow by about $2 \mathrm{ft}^{3} / \mathrm{s}$ and reduced heads in the aquifer by $1.74 \mathrm{ft}$.

The model parameters were adjusted until the simulated water levels acceptably matched corresponding measured water levels. Accuracy of the steady-state model was determined by comparing the absolute error between the al titude of the measured water levels and the altitude of the simulated water levels. This was calculated by adding the absolute value of the difference between water levels, in all 11 observation wells that were measured from 1970-79, and simulated water levels, in the appropriate cell, and dividing by 11 . The average absolute difference between measured water levels and simulated water levels was $1.57 \mathrm{ft}$. This difference was considered to be an acceptable error because it is less than the average measured head change or gradient across each cell of about $2 \mathrm{ft}$. The average absolute difference additionally could have been reduced by adjusting the model's recharge, evapotranspiration, and aquifer characteristics. However, the adjustment to these parameters would have been outside of the plausible ranges previously established. If all the simulated water-level values that are higher than the measured water-level values are added and all the lower values are subtracted, the average simulated water level was $0.4 \mathrm{ft}$ higher than the measured water level. Table 2 shows the simulated hydrologic budget for the steady-state model.

Table 2.--Simulated hydrologic budget for the steady-state model

\begin{tabular}{|c|c|c|}
\hline Budget component & $\begin{array}{c}\text { Rate } \\
\text { (acre-feet per year) }\end{array}$ & Percent \\
\hline \multicolumn{3}{|l|}{ INFLOW } \\
\hline Recharge from precipitation & 15,500 & 100 \\
\hline Total inflow & 15,500 & 100 \\
\hline \multicolumn{3}{|l|}{ OUTFLOW } \\
\hline $\begin{array}{l}\text { Discharge to the Big Sioux River } \\
\text { Evapotranspiration } \\
\text { Pumpage }\end{array}$ & $\begin{array}{l}5,500 \\
8,800 \\
1,200\end{array}$ & $\begin{array}{r}35 \\
58 \\
7\end{array}$ \\
\hline Total outflow & 15,500 & 100 \\
\hline
\end{tabular}




\section{Transient Condition}

To use the digital model as a management tool and to increase the confidence in the model results, the model needs to be able to simulate past hydrologic conditions. Hydrologic conditions for each month during 1983 were simulated by the model. The average monthly recharge to the aquifer was calculated from all 27 observation wells installed as of 1983. A value of 20 percent was assumed for specific yield (Lohman, 1967). Monthly evapotranspiration rates were assumed to be 75 percent of the monthly pan evaporation rates and were obtained from the National Weather Service station located $25 \mathrm{mi}$ west of Flandreau. River stage height, used as input in computing the riverbed leakage, was estimated between eight known river stage heights (fig. 7 ) on the river. Seven river stage sites are within the model area and one is south of the model area at the Dell Rapids streamflow gaging station (fig. 3). These values were changed each month during the transient simulation based on the measured change at the known points.

Initial conditions for simulating 1983 hydrologic conditions involved the following steps: (1) Simulated steady-state heads for the period 1970-79 were used as initial conditions for a 1975 transient simulation; (2) annual transient simulations for 1976-81 were completed using the simulated head at the end of each transient simulation period for the initial conditions for the beginning of the subsequent simulation period; (3) the 1981 simulated heads were used for initial conditions for monthly 1982 transient simulations; and (4) the December 1982 simulated heads were used for initial conditions for January 1983.

Measured water-level decline in 27 observation wells was compared with simulated water-level decline under transient conditions. The average measured water-level decline from April to October 1983 was $4.57 \mathrm{ft}$, compared to an average simulated water-level decline of $2.40 \mathrm{ft}$. The average percent difference was 45 percent and the average percent accuracy was 55 percent. The average percent difference is defined as the measured water-level decline minus the simulated water-level decline divided by the measured water-level decline. A negative difference indicates that the model overestimated the water-level decline and a positive difference indicates that the model underestimated the water-level decline. Percent accuracy is defined as the absolute value of the average percent difference subtracted from 100 .

The average monthly difference between measured and simulated water levels ranged $\mathrm{from} 1.18$ to $3.47 \mathrm{ft}$ and averaged $2.20 \mathrm{ft}$. The average absolute value of the monthly difference between measured and simulated water levels ranged from 2.47 to $3.73 \mathrm{ft}$ and averaged $3.06 \mathrm{ft}$.

A reduction in specific yield to 0.15 improved the match between measured and simulated water-level decline. Simulated water-level decline increased from 2.40 to $3.18 \mathrm{ft}$ (table 3). The average percent difference between measured and simulated water-level decline decreased from 45 to 30 percent, thus, the percent accuracy, by previous definition, increased from 55 to 70 percent. The average monthly difference between measured and simulated water levels ranged from 1.71 to $3.69 \mathrm{ft}$ and averaged $2.63 \mathrm{ft}$ (table 4). The absolute value of the average monthly difference between measured and simulated water levels ranged from 2.71 to $4.05 \mathrm{ft}$ and averaged $3.32 \mathrm{ft}$. Additional reduction of specific yield did not improve the match between the absolute value of the average monthly difference or the match between the measured and simulated water-level decline. Hydrographs of measured versus simulated water levels and corresponding percent accuracy is shown in figure 10. Measured and simulated potentiometric contours in the aquifer for 1983 hydrologic conditions are shown in figure 11 . 


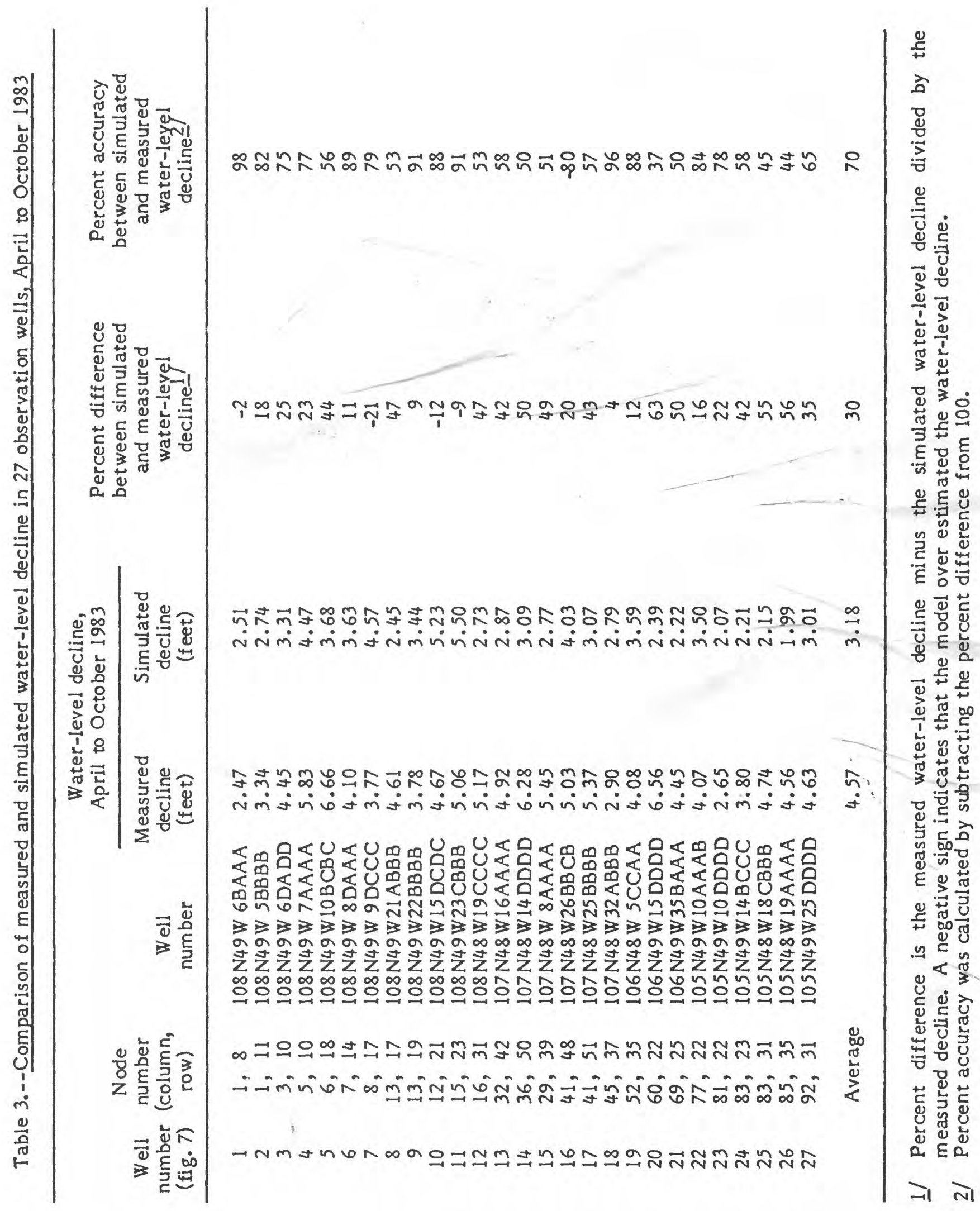


Table 4.--Summary of differences between measured and simulated water levels during 1983 by month

\begin{tabular}{|c|c|c|c|}
\hline & $\begin{array}{c}\text { Number } \\
\text { of } \\
\text { wells }\end{array}$ & $\begin{array}{c}\text { Average difference } \\
\text { between measured } \\
\text { water level and } \\
\text { simulated water level I/ } \\
\text { (feet) }\end{array}$ & $\begin{array}{c}\text { Average absolute } \\
\text { difference between } \\
\text { measured water level and } \\
\text { simulated water level } 2 \\
\text { (feet) }\end{array}$ \\
\hline January & 35 & 3.50 & 3.79 \\
\hline February & - & - & - \\
\hline March & 31 & 3.69 & 4.05 \\
\hline April & 34 & 3.30 & 3.56 \\
\hline May & 38 & 2.43 & 3.09 \\
\hline June & 38 & 2.39 & 3.42 \\
\hline July & 37 & 2.80 & 3.21 \\
\hline August & 39 & 2.34 & 2.88 \\
\hline September & 40 & 1.71 & 2.71 \\
\hline October & 43 & 2.36 & 3.21 \\
\hline November & 43 & 2.11 & 3.23 \\
\hline December & 26 & 2.31 & 3.33 \\
\hline Average & & 2.63 & 3.31 \\
\hline
\end{tabular}

1/ Calculated by the summaton of the number of wells values obtained by subtracting the simulated water level from the measured water level and dividing by the number of wells.

2/ Calculated by the summation of the number of wells absolute values obtained by subtracting the simulated water level from the measured water levels and dividing by the number of wells. 

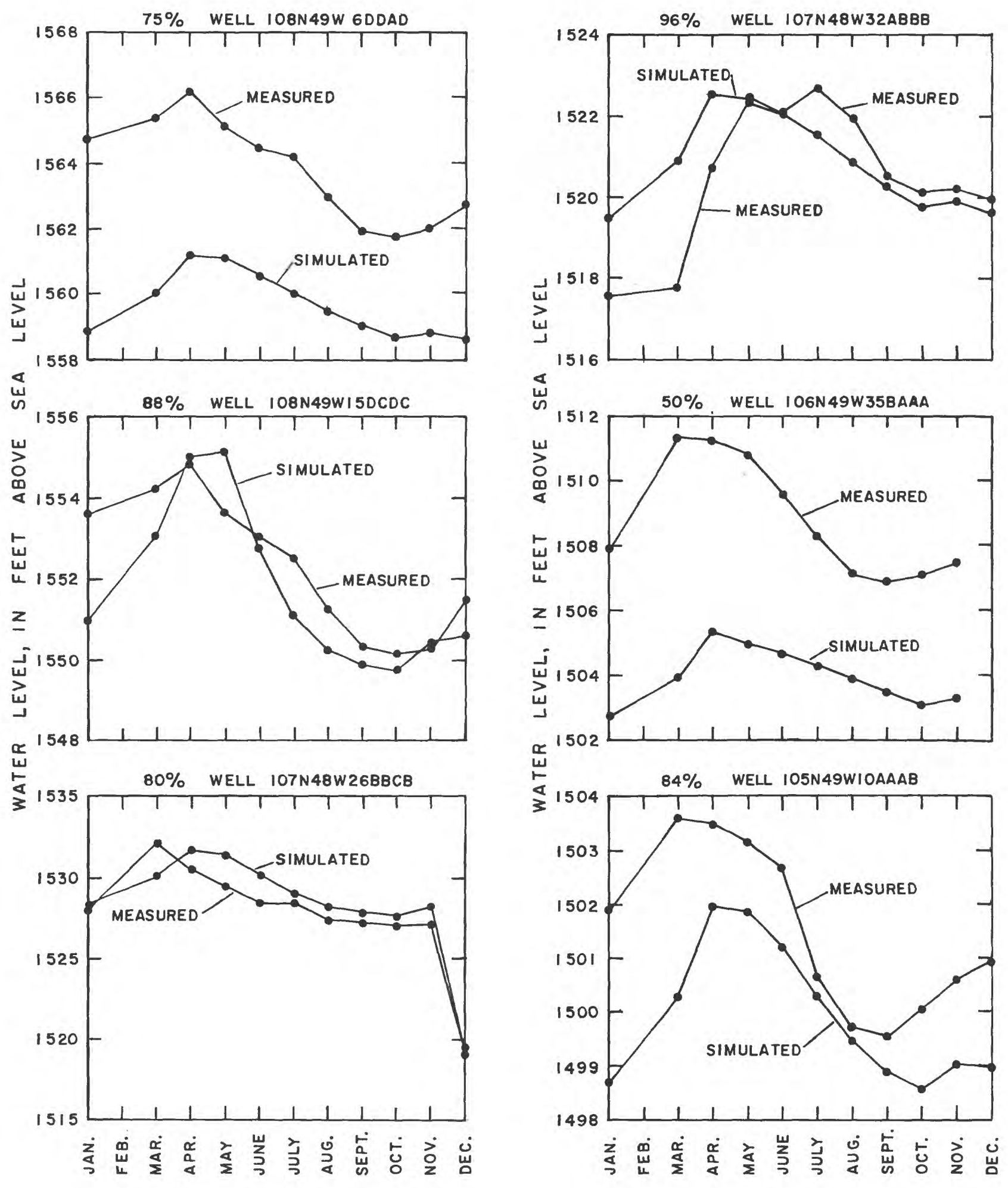

Figure 10.--Comparison of simulated and measured water levels and percent accuracy of six wells completed in the Big Sioux aquifer, 1983. 


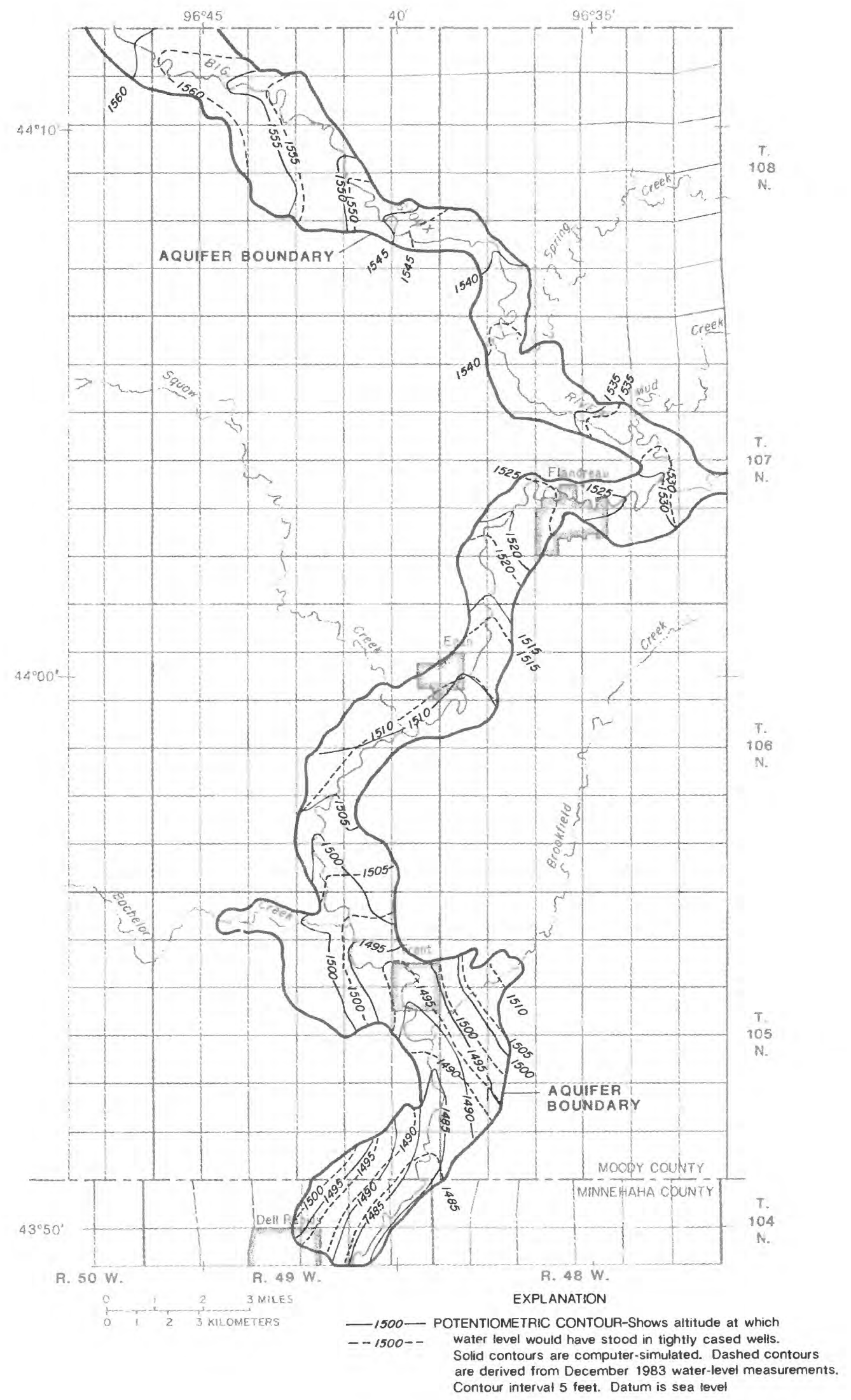

Figure 11.--Comparison of computer-simulated and measured potentiometric surfaces in the Big Sioux aquifer. 
The primary discharge from the Big Sioux aquifer during 1983 was evapotranspiration (table 5). This discharge was offset by recharge to the aquifer from precipitation and snowmelt from February to May and November. Table 5 also shows that pumpage from municipal and irrigation wells is only 1.7 percent of the total annual water budget.

\section{Sensitivity Analysis for Steady-State Conditions}

The sensitivity of simulated water levels for the steady-state model to changes in recharge, riverbed hydraulic conductivity, aquifer hydraulic conductivity, evapotranspiration rate, and evapotranspiration extinction depth was analyzed. The results of this sensitivity analysis are summarized in table 6. Changes in the recharge rate and riverbed hydraulic conductivity affected simulated water levels the most. Simulated water levels rose an average of $1.76 \mathrm{ft}$ in response to a $4.1-\mathrm{in} / \mathrm{yr}$ increase in recharge rate. Increasing riverbed hydraulic conductivity by a factor of 10 resulted in a $1.74-\mathrm{ft}$ decrease in simulated water levels. Simulated water levels were least sensitive to aquifer hydraulic conductivity, and were sensitive to evapotranspiration extinction depth. Simulated water levels declined an average of $0.27 \mathrm{ft}$ in response to a 30 percent increase in aquifer hydraulic conductivity, rose by $0.42 \mathrm{ft}$ in response to a 30 percent decrease of aquifer hydraulic conductivity, and declined $0.8 \mathrm{ft}$ in response to $2.5 \mathrm{ft}$ increase in evapotranspiration extinction depth.

Steady-state sensitivity analysis for boundary conditions were conducted to determine whether or not boundaries represented in the model accurately represented boundaries in the project area. The no-flow boundary was replaced with a general head boundary (McDonald and Harbaugh, 1984). The general head boundary simulates leakage from the surrounding glacial till. The simulated steady-state water-level change, because of this boundary, was less than $0.5 \mathrm{ft}$. The Big Sioux River was represented as constant head boundary instead of a leaky stream boundary as represented by the river package. Simulated water levels were 5 to $6 \mathrm{ft}$ less than measured water levels when the river was represented as a constant head boundary. Also, cells near the boundary dried up. The constant head boundary allowed too much water to enter the river which drained the aquifer, and caused the lower simulated water levels.

The sensitivity analysis showed that the model's simulated water levels are least sensitive to changes in aquifer hydraulic conductivity and are most sensitive to changes in recharge. The water levels simulated by the model were affected to a greater extent by evapotranspiration extinction depth than by the evapotranspiration rate.

\section{Analysis of Hypothetical Hydrologic Situations}

The model was used to simulate the effects of hypothetical hydrologic situations. As ground water is withdrawn under transient conditions, water levels decline and water is released from storage. Conversely, steady-state recharge-discharge relationships change depending on the volume of ground-water withdrawals, location of wells, and natural recharge to and discharge from the aquifer. Ground water discharge to streams or to evapotranspiration may be diverted to wells because of increased ground-water withdrawals. If ground-water withdrawals continue for a long enough period of time, and do not exceed potential increase in recharge to the aquifer, or potential decrease in discharge from the aquifer, new steady-state hydrologic conditions will occur (the new recharge and discharge rates will approach equilibrium). 


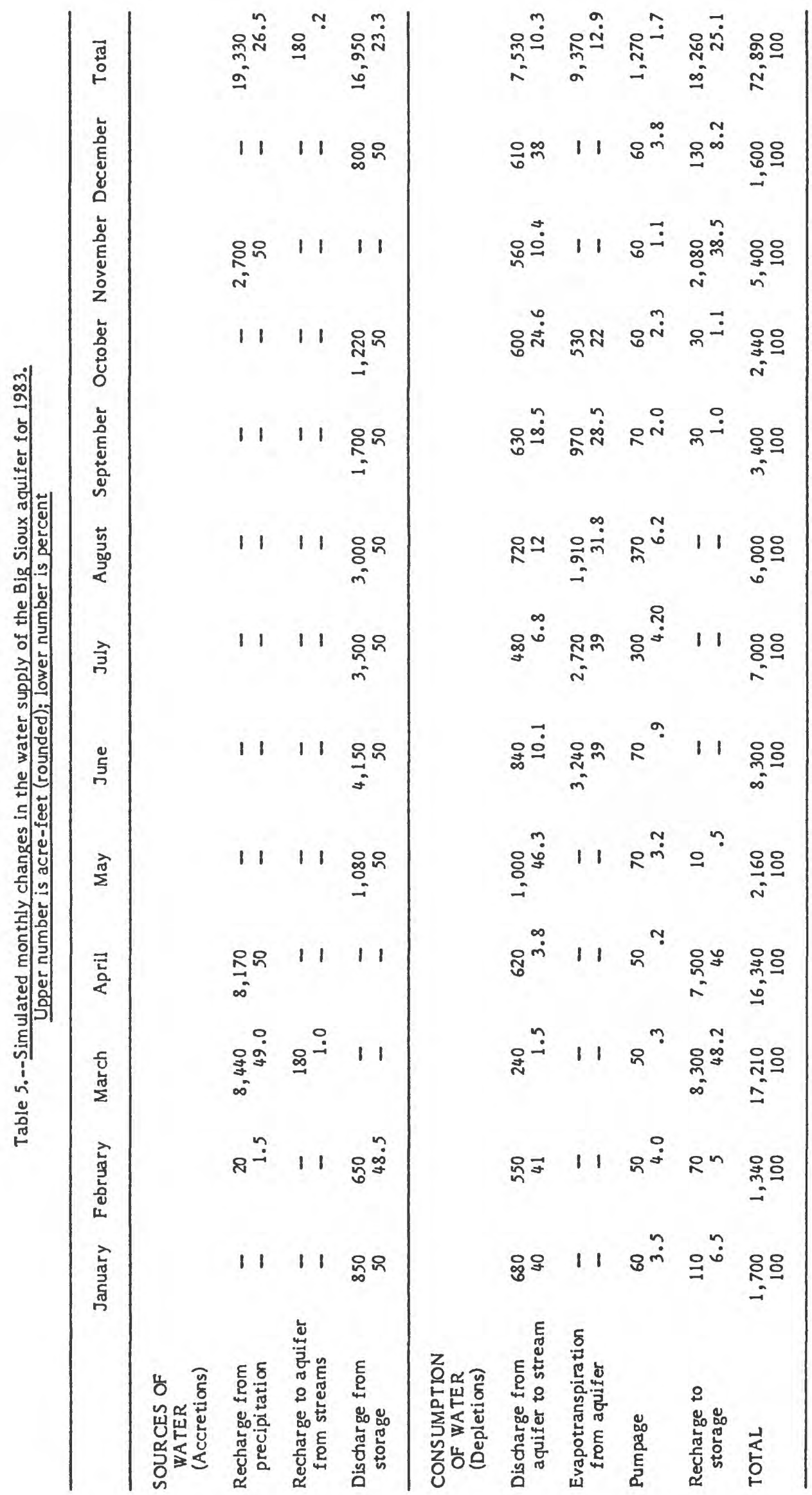




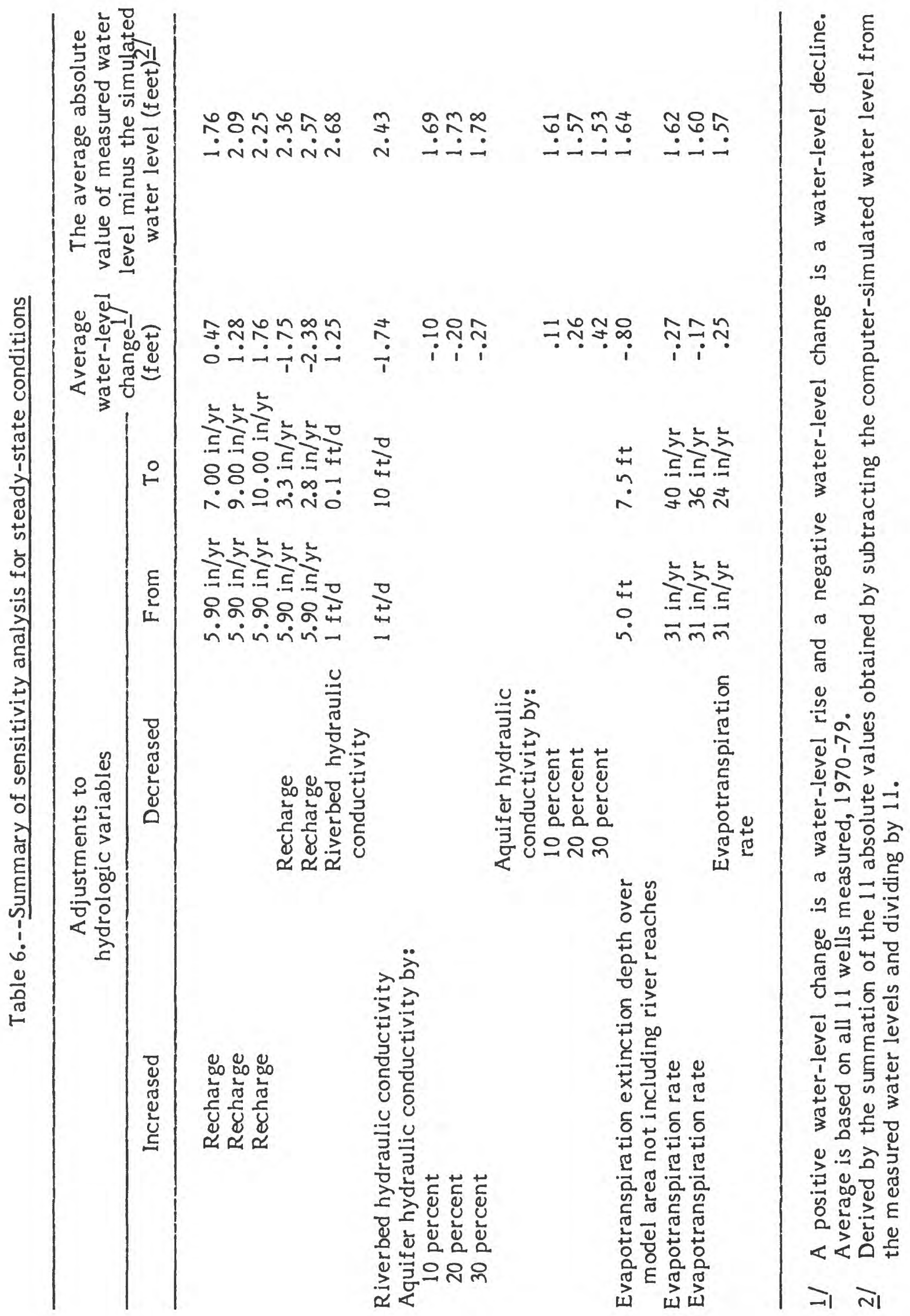


The aquifer was evaluated under three hypothetical hydrologic situations: (1) Severe 1976 drought conditions under transient conditions; (2) withdrawals from 50 hypothetical wells under average 1970-79 conditions; and (3) withdrawals from the same 50 hypothetical wells under transient conditions during the severe 1976 drought. The first hypothetical situation was designed to estimate the water-level declines caused by present development (1983) under drought conditions similar to the 1976 drought. The second and third hypothetical situations were designed to appraise the aquifer's potential for future development and the effects of this development during a severe drought.

\section{Severe 1976 Drought Conditions, Hypothetical Situation 1}

Severe 1976 drought conditions were simulated to evaluate the transient effects of pumping at 1976 pumping rates from wells installed as of 1983. Precipitation, streamflow, and water levels measured during 1976 were used as initial conditions for the simulation. The average pumping rate for irrigation in 1976 was apportioned between 20 wells (fig. 12), some of which were installed after 1976. Monthly pumping, evapotranspiration, and recharge rates used in the simulation are shown in table 7. The river-stage height was estimated between the Brookings and Dell Rapids gages. The height was changed each month at each river reach during the simulation, based on the measured change at the gages. Because streamflow measured at Dell Rapids was zero and was $0.01 \mathrm{ft}^{3} / \mathrm{s}$ near Brookings during August and September, the river was not simulated during these months.

Table 7.--Monthly hydrologic conditions and pumping rates for severe drought conditions (1976), hypothetical situation 1

\begin{tabular}{|c|c|c|c|}
\hline & $\begin{array}{c}\text { Recharge rate } \\
\text { (acre-feet per month) }\end{array}$ & $\begin{array}{c}\text { Maximum } \\
\text { evapotranspiration } \\
\text { rate } \\
\text { (acre-feet per month) }\end{array}$ & $\begin{array}{c}\text { Pumping rate } \\
\text { (all wells as } \\
\text { of 1983) } \\
\text { (acre-feet per month) }\end{array}$ \\
\hline January & 0 & 0 & 10 \\
\hline February & 0 & 0 & 10 \\
\hline March & 7,490 & 0 & 10 \\
\hline April & 0 & 0 & 10 \\
\hline May & 0 & 27,600 & 130 \\
\hline June & 0 & 36,400 & 590 \\
\hline July & 0 & 37,500 & 720 \\
\hline August & 0 & 33,600 & 600 \\
\hline September & 0 & 23,200 & 130 \\
\hline October & 0 & 0 & 10 \\
\hline November & 0 & 0 & 10 \\
\hline December & 0 & 0 & 10 \\
\hline
\end{tabular}


The drawdown after 12 months of pumping under the 1976 hypothetical drought conditions and pumping rates from irrigation and municipal wells that existed in 1983 is shown in figure 12. The average simulated drawdown was about $3 \mathrm{ft}$. The maximum simulated drawdown was as much as $12 \mathrm{ft}$ near the northern boundary of the aquifer. The no-flow boundary condition selected along the northern boundary of the model may not closely simulate the actual hydrologic conditions and may have caused the large drawdown in the area. Moving the location of the hypothetical pumping well one cell south of the no-flow boundary reduced drawdown by about $5 \mathrm{ft}$. None of the cells were simulated as going dry after 12 months of pumping. The monthly changes in the water supply are shown in table 8. The monthly changes show that the largest single item on the depletion side is evapotranspiration. This was offset by discharge from storage. Note that from tables 5 and 8 during drought conditions, pumpage of irrigation and municipal wells has increased about 900 acre-ft. In 1983, an average year for precipitation, there was very little change in storage (table 5), compared to a net loss of about 11,000 acre-ft from storage during 1976 (table 8).

\section{Increased Withdrawals, Steady-State Conditions, Hypothetical Situation 2}

The steady-state model was modified to evaluate the effects of increased pumpage from the aquifer. Input for this simulation was based on average hydrologic conditions for the period 1970-79. Fifty hypothetical wells were placed throughout the aquifer and were each pumped at $104 \mathrm{acre}-\mathrm{ft} / \mathrm{yr}$ for a total withdrawal of 5,200 acre-ft/yr. The hydrologic budget for this simulation is shown in table 9. Evapotranspiration from the aquifer was 3,200 acre-ft less under the smaller average pumpage from 1970-79 (table 2). There was $100 \mathrm{acre}-\mathrm{ft} / \mathrm{yr}$ of recharge to the aquifer from the Big Sioux River and 2,100 acre-ft less discharge from the aquifer to the Big Sioux River than occurred from the average pumpage of 1970-79 (table 2). The average simulated drawdown was about $2 \mathrm{ft}$, and the maximum simulated drawdown caused by the 50 additional wells was $4.5 \mathrm{ft}$ (fig. 13).

Increased Withdrawals during Severe Drought Conditions, Hypothetical Situation 3

The model was further modified to evaluate the transient effects of increased pumping under 1976 drought conditions. This simulation used 50 hypothetical wells with the same locations and pumping rates as in the previous steady-state simulation. Twelve monthly simulations beginning in January were made under 1976 drought conditions (table 10). The simulated drawdown after 12 months (fig. 14) ranged from 1 to $7 \mathrm{ft}$ and averaged about $3 \mathrm{ft}$. None of the cells were simulated as becoming unsaturated. The largest drawdowns occurred along the northern boundary of the model area and may be the result of the proximity of the model boundary. The comparison of tables 8 and 10 indicate that about 5,200 acre-ft of water was removed from storage by the 50 wells. Evapotranspiration was decreased by about 1,100 acre-ft because of the increased drawdown from the 50 additional wells. 


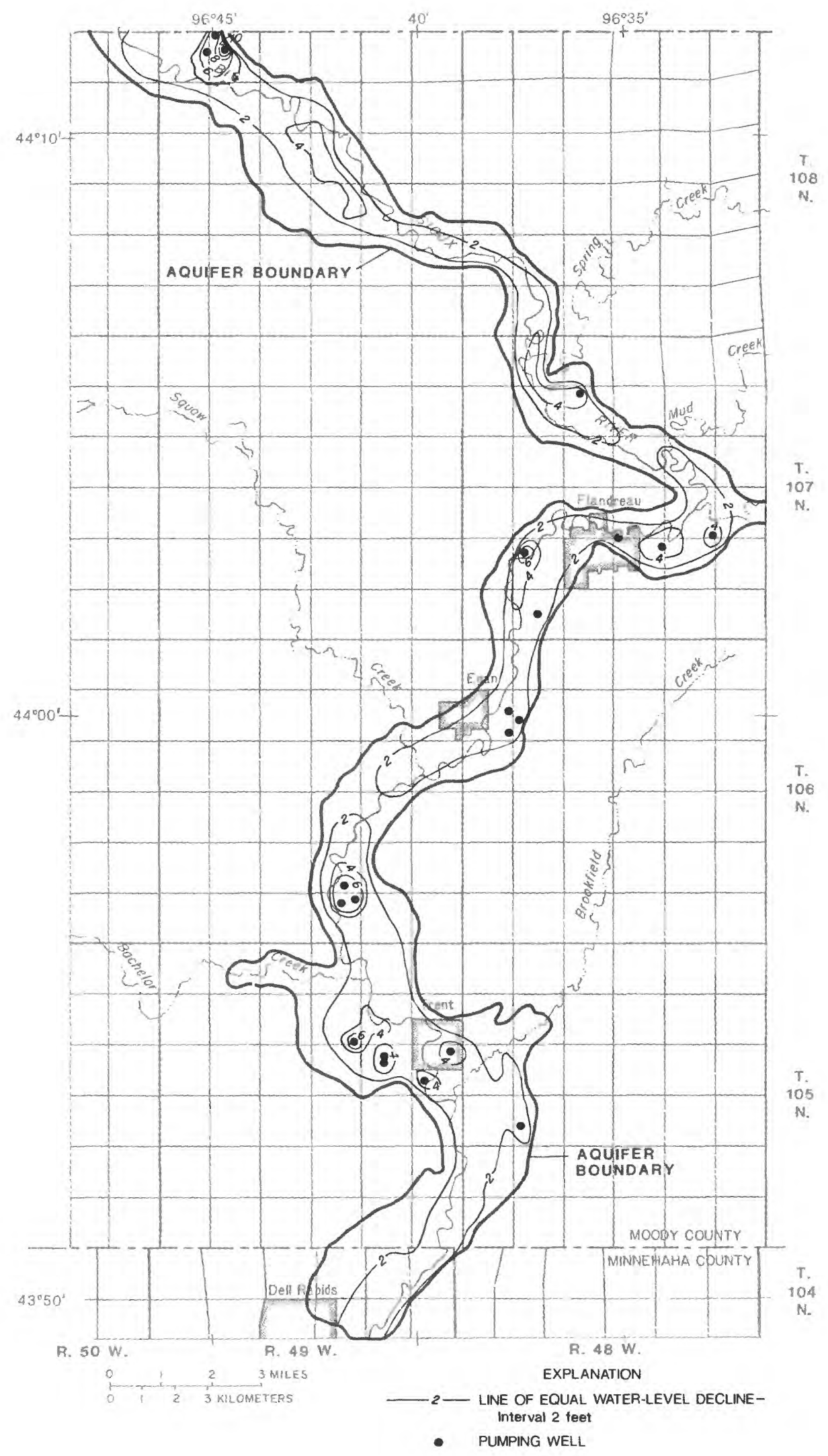

Figure 12.--Simulated drawdown after 12 months of pumping under drought conditions (1976), hypothetical situation 1. 


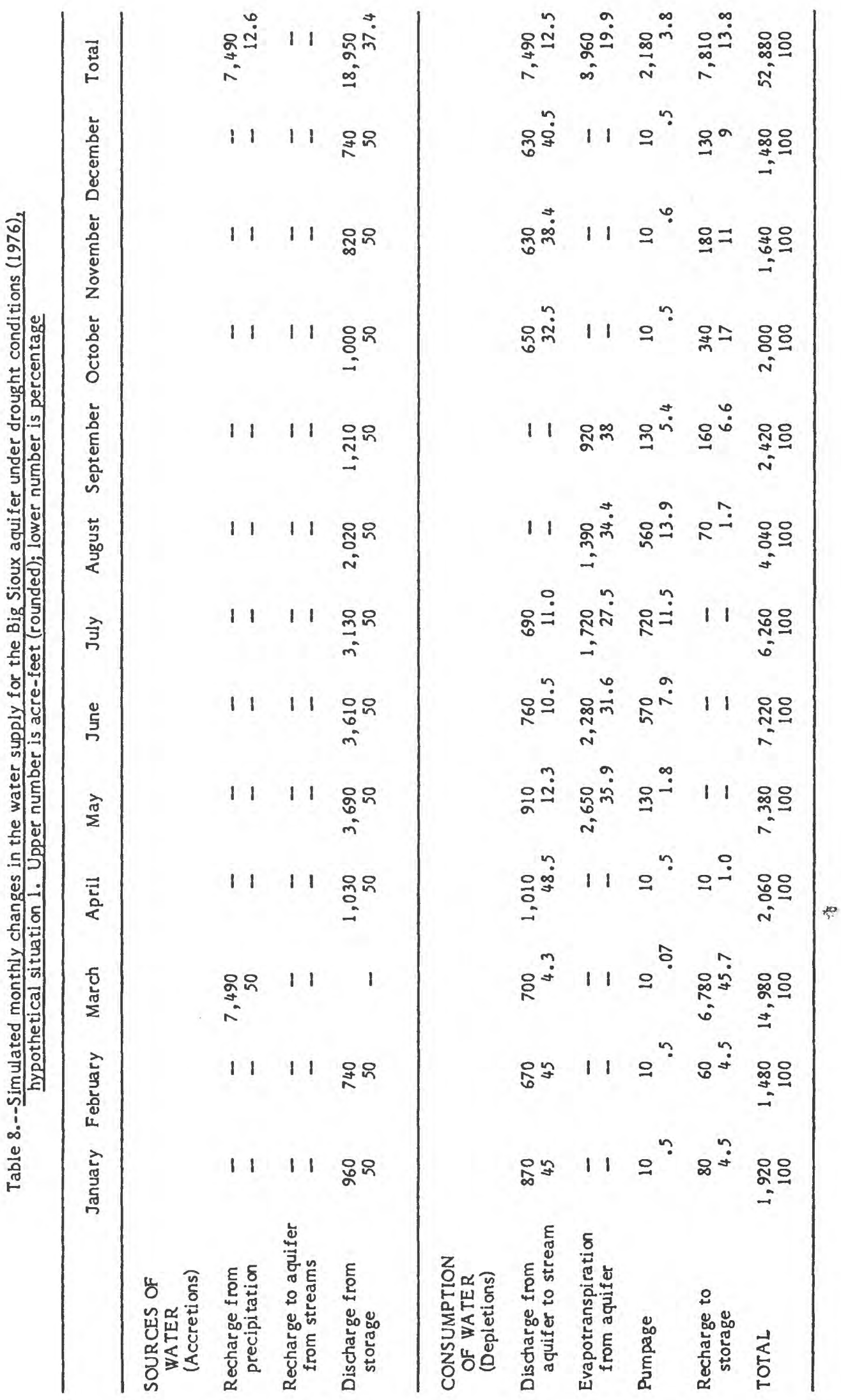


Table 9.--Increased withdrawals, steady-state conditions, hypothetical situation 2

Budget component

Rate

(acre-feet per year)

Percent

\section{INFLOW}

Recharge from precipitation

Recharge from the Big Sioux River

¿tal inflow

15,500

99

100

1

$-1$

15,600

100

OUTFL OW

Discharge to the Big Sioux River

Evapotranspiration

Pumpage

$\begin{array}{ll}3,400 & 24 \\ 5,600 & 40 \\ 5,200 & 36\end{array}$

5,200

36

Total outflow

14,200

100 


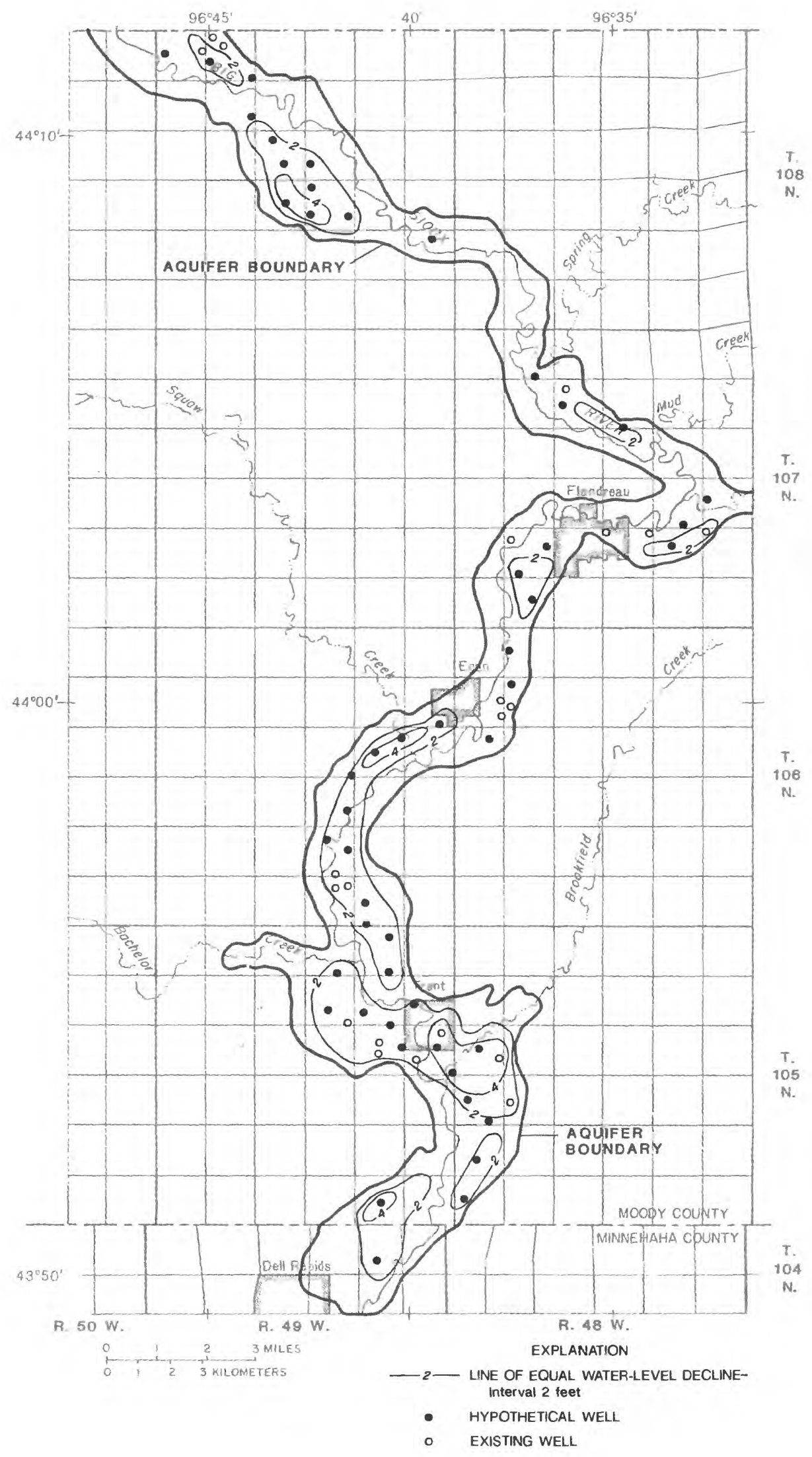

Figure 13.--Simulated steady-state drawdown based on 1970-79 data, under increased withdrawals, hypothetical situation 2. 


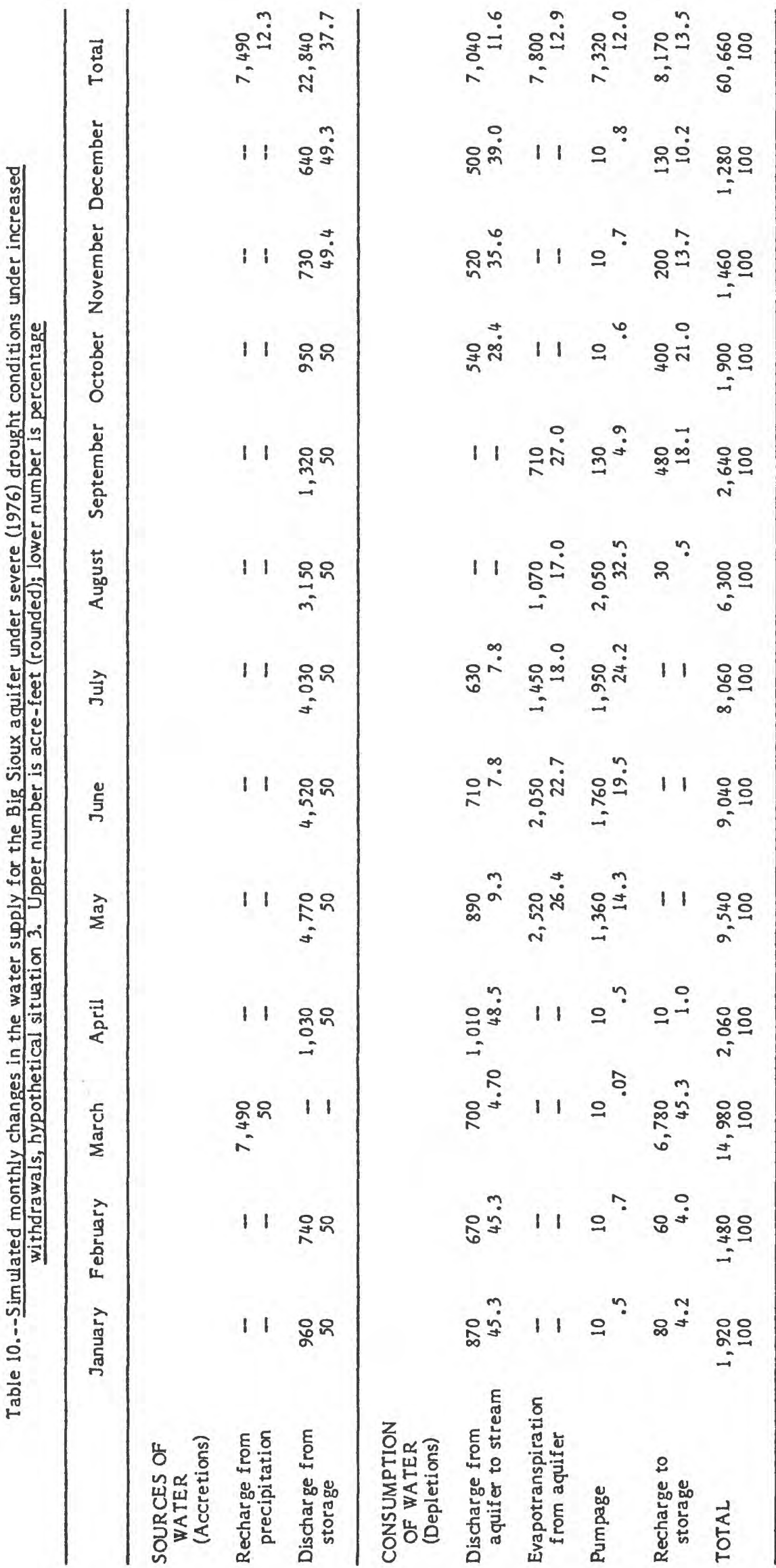




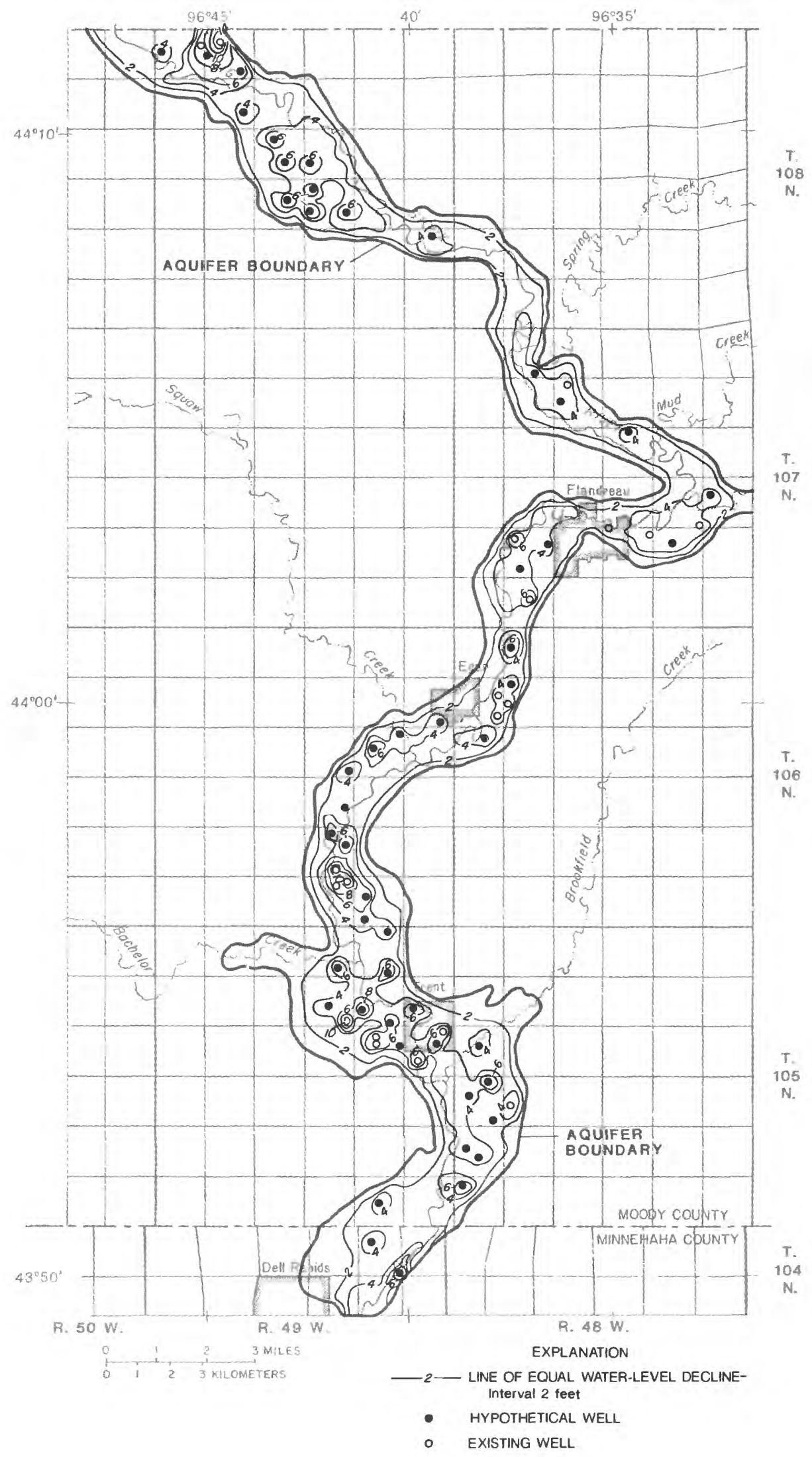

Figure 14.--Simulated drawdown after 12 months pumping under drought (1976) conditions with increased withdrawals, hypothetical situation 3. 


\section{MODEL LIMITATIONS}

All hydrologic models have certain limitations because a similar calibration could have been achieved with a different set of values for the hydrologic characteristics, evapotranspiration, and recharge. A similar model calibration could have been obtained by adjusting recharge, which was uniform over the area, and then adjusting the evapotranspiration extinction depth to compensate for the simulated change in water levels. Since evapotranspiration extinction depth data is not a measured value, the calibration obtained for the model presented in this report is not unique. Because there are no independent estimates of actual evapotranspiration or specific yield, this model is less constrained than most, and the simulated response to drought or increased pumping could be subject to corresponding large errors. The streambed hydraulic conductivity also is not a measured value, thus the simulated leakage from aquifer to the Big Sioux River and evapotranspiration is not accurately quantified. The storage coefficient is an assumed value which was used to calculate recharge to the aquifer. Thus, recharge to the aquifer is not directly measured and is likewise an assumed value.

\section{SUMMARY}

The Big Sioux aquifer is composed of fine to coarse sand and gravel deposited as glacial outwash. The 55-square-mile water-table aquifer is hydraulically connected to the Big Sioux River. The aquifer is as much as $54 \mathrm{feet}$ thick and averages $22 \mathrm{feet}$ thick. Average annual precipitation for the study area, 479 square miles, is about 22 inches per year (564,600 acre-feet per year). Of this amount, 6,200 acre-feet per year leaves the ground-water system as discharge to streams, 3,100 acre-feet per year is removed by pumpage, and 555,300 acre-feet per year is returned to the atmosphere by evapotranspiration.

A digital model was developed to simulate ground-water flow in the aquifer and was adjusted to simulate steady-state and transient conditions. Average hydrologic conditions for pumpage, recharge, evapotranspiration rates, river-stage heights, and hydraulic head were determined for $1970-79$ for the steady-state calibration. Ten wells were used to compare the measured water levels with the simulated water levels. The average absolute difference between measured and simulated water levels was 1.56 feet. For 1970-79, the period on which the steady-state calibration is based, measured water levels in 10 wells fluctuated as much as $8.0 \mathrm{feet}$. The average simulated water-levels were 0.9 feet higher than measured water-levels.

The transient calibration was made for 1983. Simulated water levels were compared with measured water levels in 27 observation wells. The measured water levels declined an average of $1.10 \mathrm{feet}$ while simulated water levels declined an average of $1.4 \mathrm{feet}$. The measured water-level decline from April to October 1983 was $4.57 \mathrm{feet}$ compared to the simulated water-level decline of $2.40 \mathrm{feet}$. The monthly difference between measured and simulated water levels ranged from 1.18 to $3.47 \mathrm{feet}$ and averaged 3.06 feet.

Sensitivity analyses of the steady-state model showed simulated water levels were most sensitive to adjustments to recharge rate and evapotranspiration extinction depth. Simulated water levels rose $1.7 \mathrm{feet}$ in response to a 4 -inch-per-year increase in recharge rate. Simulated water levels declined $0.8 \mathrm{foot}$ in response to a 2.5 -feet increase in evapotranspiration extinction depth. Simulated water levels were least sensitive to adjustments in aquifer hydraulic conductivity. Simulated water levels declined an average of $0.27 \mathrm{foot}$ in response to a 30 percent increase in aquifer hydraulic conductivity. 
The calibrated model was used to study the effects of water levels in the aquifer under three hypothetical situations. The first hypothetical situation simulated the transient effects of withdrawals from wells existing in 1983 under severe drought conditions. The average simulated drawdown was about 3 feet. Drawdown in the aquifer was as much as 12 feet and no nodes went dry in the model.

The second hypothetical hydrologic situation evaluated the effects of increased withdrawals from 50 hypothetical wells pumping about 5,200 acre-feet per year under steady-state hydrologic conditions. The average simulated drawdown was about 2 feet and the maximum simulated drawdown was 4.5 feet.

The third hypothetical hydrologic situation used the same hypothetical well locations and pumpage rates as in the previous simulation under severe drought conditions. Simulated drawdown ranged from 1 to $7 \mathrm{feet}$ and averaged about 3 feet, and no nodes went dry in the model.

\section{SELECTED REFERENCES}

Eagleman, J. R., 1967, Pan evaporation, potential and actual evapotranspiration: Journal of applied meteorology, v. 6, no. 3, p. 482-488.

Ellis, M. J., and Adolphson, D. G., 1969, Basic hydrologic data, for a part of the Big Sioux drainage basin, eastern South Dakota: South Dakota Geological Survey and South Dakota Water Resources Commission, Water Resources Report 5, $124 \mathrm{P}$.

Ellis, M. J., and others, 1969, Hydrology of a part of the Big Sioux drainage basin, eastern South Dakota: U.S. Geological Survey Hydrologic Investigations Atlas HA-311 (with 5 p. pamphlet text).

Hansen, D. S., 1982, Gravity delineation of a buried valley in quartzite: Ground Water, v. 22 , no. 6 , p. $773-779$.

-..- 1984, Water resources of Lake and Moody Counties, South Dakota: U.S. Geological Survey Water-Resources Investigations Report $84-4209$.

Henry, M. J., 1982, Hydraulic conductivity of glacial till in Alberta: Ground Water, March-April 1982, p. 162.

Jorgensen, D. G., and Ackroyd, E. A., 1973, Water resources of the Big Sioux River valley near Sioux Falls, South Dakota: U.S. Geological Survey Water-Supply Paper 2024, 50 p.

Koch, N. C., 1970, A graphic presentation of stream gain or loss as an aid in understanding streamflow characteristics: Water Resources Research, v. 6, no. 1, P. 239-245.

-..-1980, Appraisal of the water resources of the Big Sioux aquifer, Brookings, Deuel, and Hamlin Counties, South Dakota: U.S. Geological Survey Water-Resources Investigations Report $80-100,46$ p.

-..-1982, A digital computer model of the Big Sioux aquifer in Minnehaha County, South Dakota: U.S. Geological Survey Water-Resources Investigations Report $82-4064,49$ p. 
Larimer, O. J., 1970, A proposed streamflow data program for South Dakota: U.S. Geological Survey Open-File Report 70-194, 46 p.

Linsley, R. K., 1975, Hydrology for engineers: New York, McGraw-Hill, 2nd ed., p. $223-234$.

Lohman, S. W., 1967, Australian Water Resources Council: Ground Water School Lecture Notes, 1967, Adelaid, Australia.

McDonald, M. G., and Harbaugh, A. W., 1984, A modular three-dimensional finite difference ground water flow model: U.S. Geological Survey Open-File Report 83-875, 528 p.

National Oceanic and Atmospheric Administration, 1982, Evaporation atlas for the contiguous United States: Technical Report 33.

-.-. 1982, Mean monthly, seasonal, and annual pan evaporation for the United States: Technical Report 34.

U.S. Department of Agriculture, 1973, Water and related land resource Big Sioux River Basin and related areas, South Dakota-Minnesota-Iowa: Soil Conservation Service.

U.S. Geological Survey, 1971-75, Water resources data for South Dakota, 1970-74--part 1. Surface water records: U.S. Geological Survey Water-Data Reports SD-70-1 to SD-74-1 (published annually).

----1976-84, Water resources data for South Dakota, water years 1975-83: U.S. Geological Survey Water-Data Reports SD-75-1 to SD-83-1 (published annually). 